\title{
Kierkegaard en el «Brand» de Ibsen
}

\section{KIERKEGAARD VIVO}

Kierkegaard murió en Copenhague el año 1855 y «renació» en Alemania a principios del siglo $\mathrm{XX}$, invadiendo posteriormente otros países. Esto significa que «vive» entre nosotros, si bien es verdad que a veces aparece algo desfigurado: de él podemos decir que alcanzó la «inmortalidad» (tan anhelada por su «hermano» Unamuno), al menos la inmortalidad en la «fama» o en la «carne» de sus «hijos» espirituales. Esta pervivencia viene certificada por la multiplicidad de las influencias que el escritor de Copenhague ejerce sobre el pensamiento contemporáneo.

Por tanto, «Kierkegaard vivo» es un hecho indubitable. El pensador danés «vive» en diferentes sectores de la cultura contemporánea: en la filosofía, en la teología, en el cine, en la literatura...

Kierkegaard «vive» en las «filosofías de la existencia» del siglo $\mathrm{xX}^{1}$. La influencia del danés sobre esta modalidad filosófica contemporánea constituye un hecho evidente. Filósofos tales como J.-P. Sartre, G. Marcel, K. Jaspers, M. Heidegger, J. Hersch, J. Wahl, E. Paci.., son deudores del autor de Copenhague, al que muchos de ellos secularizaron. De él tomaron sobre todo la categoría de «existencia», a la que van unidos los conceptos de libertad, decisión, responsabilidad, concreción, nada, pecado, culpa angustia, desesperación, absurdo, muerte...

Kierkegaard «vive» en la «teología dialéctica» de Karl y Heinrich Barth, Gogarten, Brunner, Thurneysen... Estos teólogos heredan de Kierkegaard la concepción irracional de la religión, con todo lo que ello implica. Lo mismo que él, insisten en la idea de la infinita distancia cualitativa entre Dios y el

1. Cfr. AA.VV., Kierkegaard vivo, Madrid, $1970^{2}, 241 \mathrm{pp}$. 
hombre; ponen en el centro de sus teorías religiosas las categorías de contradicción, paradoja, absurdo, individualidad ante Dios, riesgo, escándalo, locura...; hacen converger en el creyente al hombre viejo y al nuevo (Adán y Cristo): la gracia y el pecado, la caída y la redención, el amor de Cristo y la cólera de Dios, la desesperación y la esperanza, el escepticismo existencial y la fe: presentan al cristiano inmerso en una dialéctica de contradicción sin mediación: no en una dialéctica de armonía y desarrollo, sino de crisis y «salto» sin posible síntesis ${ }^{2}$.

Kierkegaard «vive» en el cine, concretamente en el cine de Ingmar Bergman. Las películas de este director y autor cinematográfico sueco de principios de siglo se nutren en gran medida de los motivos existencialistas de Kierkegaard. La penosa contemplación de la condición humana, la desesperación, la soledad, la búsqueda del sentido de la vida, el misterio de la muerte, la animalidad del sexo, el problema de Dios..., constituyen algunas de las constantes de sus films. Muchas de sus obras son de un realismo sórdido y amargo; se recrean en una pintura negra de los personajes y situaciones; presentan la vida como un infierno en la tierra... ${ }^{3}$.

Kierkegaard «vive» en la literatura. Su figura ha servido de fuente de inspiración a literatos tales como H. Ibsen, R.M. Rilke, F. Kafka, A. Camus...

En este trabajo nos limitaremos a analizar la pervivencia de Kierkegaard en Henrik Ibsen 4: concretamente, en su obra titulada Brand (1866), poema dramático en el que la literatura se mezcla con la filosofía, el cual sirvió de puente entre el pensador de Copenhague y nuestro Unamuno, pues éste accedió a aquél por medio de dicha obra.

Acometemos esta empresa movidos por el deseo de desarrollar la tesis que Unamuno formula de forma sintética en su pequeño escrito titulado Ibsen y Kierkegaard (1907). Según el Rector de Salamanca, el cual empezó a aprender danés traduciendo el Brand de Ibsen 5, Kierkegaard es el «maestro» de éste, el «espíritu humano que más hondamente influyó» en el dramaturgo noruego ${ }^{6}$; más concretamente, es «el principal modelo de aquel grandioso y sombrío Brand» ibseniano 7, protagonista del drama del mismo nombre. En dicho dra-

2. Cfr. L. Aranguren, J.L., Catolicismo y protestantismo como formas de existencia, Madrid 1980, pp. 101-111; BARTH, K., Anfange der dialektischen Theologie, München 1977.

3. Cfr. CowIE, P., Ingmar Bergman, London 1962; SiClIER, J., Ingmar Bergman, Madrid 1963; DonneR, J., The personal vision of Ingmar Bergman, Indianápolis 1964.

4. GANIVET, A., Hombres del Norte, Madrid, $1971^{6}$, p. 168 , no relaciona a Ibsen con Kierkegaard, sino con Nietzsche y los anarquistas.

5. Unamuno, M. de, Ibsen y Kierkegaard, en Obras completas, Madrid, 1950, vol. III, p. 857.

6. Ibidem.

7. UnAmuno, M. de, Libros y autores españoles contemporáneos, en Obras Completas, 
ma (y en otras obras del mismo autor) se proyecta la posición religiosa de Kierkegaard: «en el fondo de la dramaturgia de Ibsen está la teología de Kierkegaard» ${ }^{8}$.

Mediante el desarrollo de esta tesis de Unamuno en el presente artículo, pretendemos conseguir tres objetivos:

1. ${ }^{\circ}$ Mostrar la presencia de la filosofía en la literatura, de donde se deduce lo conveniente que les es a los filólogos conocer la filosofía para (mejor) comprender la literatura; y hacemos esto en un momento en el que se está planteando el problema de la reforma de los planes de estudio universitarios, y se habla de la probable desaparición de la asignatura de «Filosofía» en las Facultades de Filología. De esta forma, también reivindicamos la unidad o interdisciplinariedad del saber, tan amenazada actualmente por la excesiva especialización.

2. ${ }^{\circ}$ Profundizar en el conocimiento de Kierkegaard e Ibsen, dos autores cuyas vidas coinciden en muchos puntos y cuyas obras tienen bastante de autobiográficas. Según Ortega y Gasset, «entender una obra literaria es reproducir su génesis» ${ }^{9}, \mathrm{y} / \mathrm{o}$ su proyección en el futuro, añadimos nosotros: para comprender a Feuerbach, hay que estudiar previamente a Hegel; y, conocido aquél, resulta más inteligible éste. Quien sólo conoce a un autor, ni siquiera a ese autor conoce; no se puede entender el texto sin el contexto. Empleando palabras de Leibniz, podemos decir que cada pensador es un «microcosmos»; una criatura que nació de un parto del pasado y que «está preñada de futuro». De ahí la imperante necesidad de conocer a sus antecedentes y a sus consiguientes: para entender a Ibsen, hay que estudiar a Kierkegaard, precursor de aquél; y se entiende mejor a Kierkegaard conociendo a Ibsen, seguidor de aquél.

3. Dar más «popularidad» en la Europa meridional a dos autores nórdicos (uno danés y otro noruego), pues, por lo que a la cultura se refiere, para muchos ciudadanos del sur el norte no existe.

Nuestro método de trabajo consistió en el análisis del mencionado drama de Ibsen, desde que fuimos reviviendo el pensamiento de Kierkegaard y la actitud de éste frente a la realidad. Hemos descubierto que se trata de una obra de contenido estrictamente religioso, pues reproduce de una forma simbólica y poética la diferente concepción que de la religión cristiana tenía Kierkegaard y la Iglesia oficial danesa, así como el consiguiente enfrentamiento de aquél con ésta.

cit., 1952, vol. V, p. 194. «Brand, el Brand ibseniano es su reflejo en el arte dramático, y cuanto dure Brand durará Kierkegaard». (UnAmuno, M. de, Ibsen y Kierkegaard, cit, p. 858).

8. Ibid., p. 857.

9. Otega y GaSSEt, J., Prólogo a Ganivet, A., op. cit., p. IX. 
Dado que dicha obra constituye nuestro principal punto de atención, vamos a hacer una breve referencia a los personajes y al desarrollo de la misma.

Por lo que a los personajes se refiere, en el Brand de Ibsen intervienen un protagonista y varios antagonistas; y tanto al lado de aquél como al de éstos aparecen personajes secundarios, que hacen el papel de «aliados» y prestan apoyo a sus superiores.

El protagonista, al lado del cual palidecen las otras figuras del drama, es Brand (=fuego), un pastor duro e inflexible que personifica a Kierkegaard. Aunque al principio aparece solo, pronto se unirá a él Inés, mujer ésta que nos recuerda a la novia de Kierkegaard: Regina Olsen.

Los principales antagonistas son: «el campesino», Ejnar, Gerda, «el baile», «el deán», «el pueblo». El campesino simboliza al filósofo excesivamente racionalista o especulativo (Hegel, J.L. Heiberg, etc.); va acompañado de su hijo, los secuaces de las grandes figuras de la filosofía. Ejnar e Inés al principio (después se «convierten») representan la vida estética, jovial y gozosa; creemos que su relación también tiene algo que ver con la de KierkegaardRegina Olsen. Gerda y el azor simbolizan la fantasía. El baile es un funcionario importante del Estado; le acompaña «el escribano» (secretario) y «el maestro». El deán encarna a los jerarcas de la Iglesia oficial danesa (el obispo Mynster, su sucesor Martensen...), que en último término también son funcionarios del Estado, pues aquélla está al servicio de éste; al mismo sector pertece «el sacristán». Con el baile y el deán, personajes muy materialistas, tiene bastante que ver «la madre de Brand», una anciana agonizante que se apega a las riquezas de este mundo como el calor al fuego. El pueblo simboliza la aborregada sociedad danesa del momento, adormecida en la molicie de una religión rutinaria.

Parte de la acción del drama (dividido en cinco actos) se desarrolla en un poblado de un fjord, situado en la costa occidental de Noruega; otra parte, en los alrededores. El argumento se teje en torno al personaje principal, Brand, que, en el escabroso camino que le conduce a la difícil meta que se propuso alcanzar, se va encontrando y enfrentando con los distintos antagonistas.

Concluida esta introducción, pasamos a la exposición de la visión que de Kierkegaard se trasluce en el Brand de Ibsen. Exposición que realizamos yuxtaponiendo y comparando los textos e ideas de ambos autores.

\section{REFORMADOR RELIGIOSO}

Aunque las últimas investigaciones realizadas sobre la Filosofía del derecho de Hegel y sobre la situación política de aquella época llegan a una conclu- 
sión contraria ${ }^{1}$, lo cierto es que la doble afirmación de la realidad de lo racional y de la racionalidad de lo real ${ }^{2}$, formulada por Hegel en el prólogo de dicha obra, ha sido interpretada por autores clásicos como un intento de legitimación del orden de cosas vigente. Interpretación ésta que también siguen los hegelianos daneses del siglo XIX y el mismo Kierkegaard: por el hecho de que la realidad sea producto de la razón, es racional, es como debe ser, está bien... Según Kierkegaard, los hegelianos llegan a «expresar el pensamiento... de que el mundo es bueno..., de que el género humano es la verdad o incluso es Dios...» ${ }^{3}$. De esta forma, «se diviniza lo establecido» ${ }^{4}$.

Esta idea de la justificación o divinización de lo establecido, de la Iglesia establecida concretamente, se refleja en algunas palabras que Ibsen pone en boca de dos funcionarios públicos: el baile y el deán. Ambos, al referirse a la Iglesia establecida, le aplican los supremos calificativos de «perfección», «magnificencia», «ornamento»... La ven como una realidad tan «espléndida», que produce «satisfacción» el contemplarla y es apta para la «consagración». «Lenta y tranquila nos lleva la corriente, y vemos que todo ha llegado al colmo de la perfección» (er sare godt) ${ }^{5}$. «La gente no puede estar más satisfecha. Todo les parece magnífico (gildt og rigt). Jamás vieron nada semejante» ${ }^{6}$. « $¡ Y$ se ha rematado tan felizmente la obra! ¡Está todo tan espléndidamente adornado!» (praegtingt smykket) ${ }^{7}$.

Pero Kierkegaard no está de acuerdo con esta divinización de la Iglesia oficial, llevada a cabo por los hegelianos daneses ${ }^{8}$. Para él, el mundo religioso no es perfecto, no tiene nada de espléndido o magnífico ni constituye adorno alguno: en nada se parece a un «kosmos», no es como debe ser, carece de «racionalidad», viene definido por la mediocridad y la degradación, indignas de consagración: «me he consagrado a expresar el pensamiento de que el mundo, si no malo, es mediocre...» ${ }^{9}$. Ibsen define este mundo religioso mediante el calificativo de «imperfección». Nos lo presenta como una estirpe «relaja-

1. Cfr. Álvarez Gómez, M., Fundamentación lógica del deber ser en Hegel, en Flórez, C. y Álvarez, M., Estudios sobre Kant y Hegel, Salamanca, 1982, p. 179.

2. Hegel, Grundlinien der Philosophie des Rechts, en Werke. Frankfurt am Main, 19803, vol. VII, p. 35 .

3. KIERKEGAARD, Synspunktet for min Forfatter-Virksomhed, en Samlede Vaerker. Kjovenhavn, 1906, vol. XIII, p. 572 (nota).

4. Id., Indovelse $i$ Christendom, en Samlede Vaerker, cit., 1905, vol. XII, p. 84. En lo sucesivo citado con la abreviatura IChr.

5. IBSEN, H., Brand et Dramatisk Digt. Kjovenhavn, $1898^{4}$, p. 192. En adelante citaremos esta obra mediante la abreviatura $\mathrm{Brd}$, seguida de la/s página/s en cifras arábigas.

6. Ibid., 194.

7. Ibid., 199.

8. IChr, 84.

9. KierkegAard, Synspunktet..., cit., p. 572 (nota). 
da», asolada por la «peste», por una grave «enfermedad» espiritual; como un «pueblo flojo e indolente», víctima de los «defectos», «pecados y vicios» más horrendos, «adormecido» en la molicie por la tropa dirigente de eclesiásticos... ${ }^{10}$.

Semejante degradación del mundo religioso, resultado de la influencia de la filosofía de Hegel sobre el mismo, equivale a la transformación del «cristianismo en «cristiandad», en cristianismo inauténtico; o, lo que es sinónimo a la supresión del cristianismo ${ }^{11}$.

La conciencia de la degradación de la realidad religiosa de la época, y el consiguiente desacuerdo radical con la jerarquía eclesiástica del país, llevarán a Kierkegaard a adoptar una actitud de «reformador» religioso ${ }^{12}$. El pensador danés se hace eco de lo que proclamará después Marx en la 11. ${ }^{\text {a }}$ Tesis sobre Feuerbach y se decide a transformar la realidad religiosa de su patria y de su época: a «intentar nuevamente introducir el cristianismo en la cristiandad ${ }^{13}$ o, como dice Ibsen por boca de Brand, a curar la enfermedad e imperfección del mundo religioso: «me sé venido al mundo para curar su enfermedad y su imperfección» (sot og brist) ${ }^{14}$. El pueblo danés ha sido «adormecido» en la rutina de la religión por los jerarcas de la Iglesia, y Kierkegaard quiere despertarlo ${ }^{15}$, ponerlo al revés ${ }^{16}$.

Pero, como le advierte Ejnar a Brand, esta actividad transformadora no debe caer en el error de reducirse meramente a su vertiente negativa, olvidando la dimensión positiva ${ }^{17}$ : la actitud práctica de Kierkegaard se desdobla en una crítica destructiva de la inauténtica realidad religiosa y en un intento de construcción o «edificación» alternativa de la religión auténtica.

Para definir la dimensión negativa de esta actitud práctica, Ibsen pone en relación con Brand (símbolo de Kierkegaard) una población de conceptos del mundo bélico, tales como «guerra», «caída», «lucha», «combatir», «armas», «espada», etc. Brand ha escuchado «la llamada de Dios», tiene muy claro cuál es su misión ${ }^{18}$, y quiere luchar por la causa de aquél contra los «mostruos»

10. Brd, 22-5, 36, 90, 106-7.

11. IChr, 34, 129, 208.

12. «Soy el último estadio de una escuela de poetas que aspiran a convertirse en una especie de reformadores en miniatura». (KIERKEGAARD, Diario. Ed. de C. Fabro, Brescia, 1980-83 ${ }^{3}$, VIII ${ }^{1}$ A 347). En lo sucesivo citaremos este escrito mediante la abreviatura $D i$, seguida de las siglas de la edición danesa.

13. IChr, 34.

14. Brd, 25. «El que requiere ser curado es el linaje del siglo». (Ibid., 21).

15. Ibid., $75,97,107$.

16. "Tú vuelve el mundo al revés», le reprocha Ejnar a Brand. (Ibid., 27).

17. «No apagues el rescoldo, aunque humee, antes que el fanal haya mostrado la ruta. No borres las viejas palabras del idioma hasta haber creado las palabras nuevas». (Ibid., 25).

18. Ibid., 106. 
que devastan el país. « ¡Guerra (til kamp) a diestro y siniestro contra esta triple alianza! ¡Veo mi misión asomando resplandeciente como la luz del sol a través del postigo entreabierto! Bien sé cuál es mi cometido. ¡Los tres monstruos han de pagar con su caída el dolor del mundo! ¡Si el género humano consigue encerrar a semejantes seres en la tumba, por fin desaparecerá la peste universal! ¡Arriba! ¡En guardia, alma! ¡Desenvaina tu espada! ¡A la lucha, por los hidalgos del cielo!» ${ }^{19}$. Así, pues, Brand-Kierkegaard se nos presenta como un «luchador», que ha adoptado por consigna el grito de "iguerra» ${ }^{20}$ : guerra contra la Iglesia establecida, contra la errónea idea de Dios que ésta tenía y el consiguientemente también falso concepto de individuo religioso cimentado sobre dicha idea. Está dispuesto a «luchar hasta vencer o fracasar» ${ }^{21}$.

$\mathrm{El}$ aspecto positivo de esta praxis transformadora se refleja en el intento kierkegaardiano de construir una realidad religiosa auténtica, un hombre nuevo, verdadero hombre: «arriesgadamente (afirma Brand) quise crear (skabe) el hombre nuevo, eterno, puro...» ${ }^{22}$; asume la tarea de crear de nuevo la estirpe ${ }^{23}$. En este contexto es nuclear la categoría kierkegaardiana de «edificación» a la que hace referencia Ibsen mediante la idea de «edificación de la gran Iglesia» que Brand pretende llevar a cabo ${ }^{24}$; «edificación» ésta a la que Brand da un sentido espiritual, pero que el baile y el pueblo en general entienden en el sentido material.

En relación con esta idea de edificación de la nueva Iglesia, Ibsen expresa de una forma indirecta tres ideas kierkegaardianas que vamos a reseñar a continuación. En primer lugar, la idea de que la nueva Iglesia o religión a edificar pretende ser una recuperación de la primitiva (la de los primeros cristianos de la historia), que era la auténtica, y que desde aquellos primeros tiempos se ha ido degradando progresivamente, por lo que hoy «ya no queda ni rastros» de la misma ${ }^{25}$; idea ésta que alberga una concepción romántica de la historia (de la religión), según la cual la Edad de Oro está al principio de los tiempos y se va degradando progresivamente a medida que va pasando el tiempo.

En segundo lugar, Ibsen se refiere a la herencia pecuniaria de Kierkegaard y al empleo de la misma en la construcción de una nueva Iglesia, de una religión más auténtica. Como todos sabemos, Kierkegaard heredó de su padre una cuantiosa suma de dinero, que le permitió mantenerse durante toda la vi-

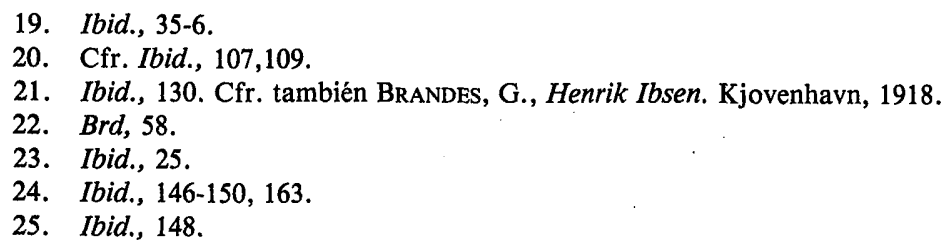


da sin necesidad de realizar ningún trabajo remunerado ${ }^{26}$; herencia ésta que fue gastando poco a poco en el sustento de la existencia física mientras escribía sus obras y en la edición de éstas, las cuales tenían como finalidad edificar el auténtico cristianismo. «No pienso (asegura Brand) hacer que se sacrifique ni un solo cobre para dar cobijo a mi Dios. Quiero edificar por mis propios medios. Mi herencia, todo lo mío, hasta la última entrega, será dado para este fin»" ${ }^{27}$.

En tercer lugar, en el Brand de Ibsen aparece reflejada la idea de Kierkegaard como «pastor universal»; pastor que no se limita exclusivamente al cuidado y construcción de una Iglesia parroquial particular, sino que extiende su ámbito de influencia a todo el país o incluso al mundo entero. Parece ser que poco antes de 1846 Kierkegaard, que había cursado los estudios de teología, tuvo la intención de abandonar su carrera de escritor y ocupar un puesto de docente en el seminario de Copenhague, o ir de pastor a alguna parroquia rural del país; muestra de esta intención es el Postcriptum concluyente... (1846), obra con la que pensaba cerrar la serie de sus escritos, como nos indica su título ${ }^{28}$. Pero luego no llegó a realizar este plan, quizás por temor a las consecuencias perniciosas a las que pudieran derivar las críticas que ya había hecho a la Iglesia oficial del país, o quizầs por el deseo de seguir siendo un «pastor universal» mediante su actividad literaria de escritor religioso, cuyos sermones o «discursos edificantes» no eran escuchados exclusivamente por los escasos feligreses de una pequeña parroquia de pueblo, sino por un público mucho más numeroso. Semejante idea la expresa Ibsen a la mitad del segundo acto de la obra, cuando un hombre del pueblo pide a Brand se quede como pastor de la parroquia; petición a la que Brand no accede, porque se siente llamado a cumplir una misión superior, que afecta a todo el mundo. «Exige lo que quieras; pero jeso nunca! Sobre mí descansa un quehacer mayor. Requiero la fuerte agitación de la vida, el oído abierto del mundo. ¿Qué había de hacer yo aquí, donde la montaña lo encierra todo, y la voz del hombre pierde su robustez? (...). ¿Quién se encierra en la cueva, cuando atrae la pradera libre y verde? (...). No osen amarrar, encadenar, retener el río de la vocación que quiere llegar hasta la bóveda marina» ${ }^{29}$.

La doble dimensión (crítica destructiva y labor constructiva) de la actitud práctica de Kierkegaard está en cierto modo reflejada en todo el primer acto del drama de Ibsen, que viene a ser una especie de resumen anticipado de toda

26. Cfr. Brandt, F. y Rammel, E., Soren Kierkegaard og Pengene. Kobenhavn, 1935.

27. Brd, 149.

28. Cfr.: $D i$, VII ${ }^{1}$ A 4; VII ${ }^{1}$ A 98; $\mathrm{X}^{5}$ A 146; Lowrie, W., A Short Life of Kierkegaard. Princeton, 1974, pp. 168-9 y 185-6.

29. Brd, 56-7. 
la obra. Concretamente las palabras con que Brand cierra dicho acto exponen de una forma muy sintética los tres defectos fundamentales que corrompen la religión de la época; defectos que Ibsen resume en tres y que se corresponden a otros tantos tipos de individuos religiosos inauténticos.

«Entre los que permanecen en el valle o la que está en la altura... ¿quién se comporta mejor? ¿Quién titubea más y avanza con más precipitación? ¿Quién se aleja más, tanteando, de la paz y del hogar? ¿El espíritu ligero que, coronado de follaje, juega al borde del más peligroso precipicio? ¿El espíritu débil que avanza maquinalmente por el camino, pues esa es la costumbre? ¿El espiritu salvaje, con tal vuelo de fantasía, que cuanto de malo ve lo transforma en hermoso?... iGuerra a diestro y siniestro contra esta triple alianza!...» ${ }^{30}$.

Estos tres tipos de individuos religiosos inauténticos, blanco de la crítica de Brand-Kierkegaard, corresponden a los siguientes personajes: el campesino, Ejnar y Gerda, los cuales simbolizan respectivamente la razón, la sensibilidad y la imaginación. Cada uno de estos personajes encarna un defecto (racionalidad, sensualidad, fantasía) de la realidad religiosa de la época, a los que Brand contrapone las tres características auténticas de la religión: irracionalidad, ascetismo y patetismo. Con lo cual, la «reforma» religiosa de Kierkegaard, tal como se refleja en el Brand de Ibsen, consiste en una sustitución de la religión racional por la irracional, de la religión estética por la ascética y, en definitiva, de la religión poética por la patética.

\section{DE LA RELIGIÓN RACIONAL A LA IRRACIONAL}

\subsection{Religión racional}

Los hegelianos daneses del ámbito de la religión, inspirándose en el principio filosófico de la racionalidad de lo real formulado por el maestro, conciben la religión cristiana como una doctrina racional, como una enseñanza cuyo destino es llegar a ser comprendida. «Se hace del cristianismo una enseñanza... El estado próximo inmediato lo constituye la «comprensión» (at «begribe») de esta enseñanza; esto es lo que hace la filosofía» ${ }^{1}$. Ven la fe como algo «inmediato», es decir, como una cualidad natural que todo el mundo posee: como un punto de partida a superar. Por tanto, el lema del individuo religioso es progresar, «ir más allá» de la fe ingenua y natural, explicarla, verterla en fórmulas lógicas. «En nuestro tiempo nadie se para en la fe, sino que todos

30. Ibid., 35 .

1. IChr, 131 . 
van más lejos... El término al que llegaban esas figuras venerables después de tantos esfuerzos, es hoy el punto de partida en que todos comienzan por las buenas para, inmediatamente, ir más lejos (at gaae videre)...» ${ }^{2}$.

Sostienen que el cristianismo, tal y como aparece expuesto en las Sagradas Escrituras y fue asimilado en los primeros siglos, «es verdadero sólo hasta cierto punto» (kun til en vis Grad er sand): su verdad está inconclusa y necesita de un acabado. Tal acabado y perfeccionamiento se lo confiere la explicación del mismo, su traducción a términos racionales. Es esta racionalidad la que le otorga el estatuto de verdad completa ${ }^{3}$.

Así, pues, en la erudita cristiandad se da una armonía entre la fe y la razón: el cristianismo se alió con la razón ${ }^{4}$, hasta el extremo de confundirse el uno con la otra como amantes apasionadamente enamorados. Y de esta «reconciliación» (Forsoning) resulta una religión cristiana totalmente luminosa y transparente para la razón, lo que implica absoluta incertidumbre y seguridad para el individuo religioso.

De todo esto se desprende que el modelo de individuo religioso que defienden los hegelianos daneses es el de un hombre perspicaz, dotado de gran capacidad para la especulación: el filósofo especulativo.

El personaje que en el Brand de Ibsen define este tipo de individuo religioso es el que lleva el nombre de «el campesino», al que va unido el concepto de «fuego» (flammer) (que en este caso significa «luz», la luz de la razón) frente a los de «oscuridad» (morke) y «tinieblas». Se trata de un hombre muy «prudente», que no quiere dar ningún paso en falso. Debido a su gran perspicacia, le molesta y atemoriza la «oscuridad», con lo que todo su afán (así como el de su hijo) consiste en sacar a Brand del ambiente tenebroso en que se encuentra, y llevarlo a donde brilla la luz solar: a donde hay claridad '5 Según nos confiesa Brand, como este campesino son casi todos los hombres de su país. "Cuando era niño... imaginaba un buho que tuviese horror a la oscuridad y un pez que tuviera horror al agua... Enfermo o sano, casi todo hombre de mi país es un buho como ése, es como uno de esos peces. Fue creado para llevar a cabo su misión en las profundidades; debiera vivir en las tinieblas de la

2. KIERKegAARd, Fryt og Baeven, en Samlede Vaerker, cit., 1901, vol. III, p. 59. En lo sucesivo citaremos esta obra mediante la abreviatura $F B$.

3. KIERKEGAARD, Afsluttende uvidenskabelig Efterskrift, en Samlede Vaerker, cit., 1902, vol. VII, pp. 194-5. En lo sucesivo citado mediante la abreviatura Eft.

4. Id., Kjerlighedens Gjerninger, en Samlede Vaerker, cit., 1903, vol. IX, pp. 189-190. En lo sucesivo citado mediante la abreviatura $K G$. Id., Begreber Angest, en Samlede Vaerker, cit., 1902, vol. IV, p. 284. En lo sucesivo citado mediante la abreviatura $B A$.

5. Brd, 7-9. 
vida, y eso es lo que le atemoriza. Se vuelve lleno de angustia al borde de la playa y rehúye su mansión estelar. Grita: «AAire y fuego diurno!» ${ }^{6}$.

Al filósofo especulativo, al hombre excesivamente racionalista, encarnado en este campesino del drama de Ibsen, también le molesta la oscuridad de los misterios y enigmas del cristianismo; no admite milagros ${ }^{7}$; no soporta el halo tenebroso que circunda la figura de Cristo, por lo que toma la decisión de transformarlo en luminosidad, en claridad racional: adopta la firme resolución de descifrar los enigmas, de explicar y hacer inteligible para todos el cristianismo. Claridad ésta que trae consigo seguridad y tranquilidad para el creyente, como se desprende de la siguiente afirmación del campesino: «estaré sentado esta noche junto al fuego» ${ }^{8}$; «fuego» que produce luz, y posición de «sentado» que nos certifica el sosiego de que goza aquél.

Esta misma idea de la racionalidad religiosa que caracteriza al campesino (símbolo del filósofo especulativo), y de la consiguiente seguridad que acompaña al creyente, la vuelve a expresar posteriormente Ibsen de un modo más directo por boca del deán, que, como hemos dicho, simboliza a los jerarcas de la Iglesia oficial danesa, algunos de los cuales eran prestigiosos teólogos. Según éstos, la fe se fundamenta en la ciencia y, por lo tanto, es un saber racional, susceptible de asimilación intelectual y de comprensión racional, lo que produce seguridad en el sujeto que la posee: «...la fe, y como está fundada en la ciencia (laerdom), puede uno fiarse de ella ciegamente; pero para instruirse en la fe...»" .

\subsection{Religión irracional}

\subsubsection{Ruptura con la razón teórica}

Frente a la religión racional de los hegelianos, Kierkegaard presenta la alternativa de una religión irracional: una religión fuera de los límites de la razón. Para el escritor religioso danés, el cristianismo y la razón son polos mutuamente excluyentes, a los que es imposible reconciliar. Y el cristianismo es incompatible con la razón porque aparece como la paradoja absoluta: «la nota característica del cristianismo es la paradoja, la paradoja absoluta (det absolute Paradox)» ${ }^{10}$. Semejante paradoja o absurdo (det Absurde) se patentiza sobre todo en un acontecimiento fundamental: la presencia en el tiempo de Cristo como Dios-hombre ${ }^{11}$.

6. Ibid., 11

7. « $\mathrm{Y}$ a la sazón había tantos milagros!... Hoy día no pasan esas cosas». (Ibid., 8). .

8. Ibid., 10 .

9. Ibid., 208 .

10. Eft, 471 .

11: Ibid., 176. 
Pero el absurdo religioso no afecta sólo al Nuevo Testamento, sino que también está presente en el contenido del Antiguo. Con lo cual, es toda la Revelación la que aparece marcada con el signo de lo absurdo: constituye un enigma indescifrable para la razón humana, ya que toda ella está plagada de misterios, de mandatos divinos incomprensibles, de comportamientos absurdos..., en los que no se ve el porqué ni el para qué.

De ahí que sea imposible una comprensión racional de la religión, un acercamiento a ella por el camino de la razón (Fornunft) ${ }^{12}$. Ésta constituye un método de análisis inadecuado para abordar el mundo de lo religioso, mundo paradojal y, por tanto, «en pugna con la razón humana» ${ }^{13}$. La única vía adecuada de acceso a lo cristiano es la fe (Tro), el oscuro camino de la fe. «Lo cristiano tiene que ser creído. Comprender (at begribe) es la actitud del hombre relativa a todo lo humano; en cambio, creer (at troe) es la única relación del hombre con lo divino" ${ }^{14}$. De esto se deduce que la fe que propugna Kierkegaard equivale a una creencia irracional, a un creer sin razones y contra la razón; por el hecho de tener un objeto paradójico supone una ruptura con la razón especulativa. «La fe exige a un hombre renunciar a su razón...» ${ }^{15}$. «Lo que importa es que quiera creer. Ahora bien, ésta es cabalmente la fórmula para perder la razón. Pues la fe significa precisamente que se pierde la razón para ganar a Dios» ${ }^{16}$.

Según Kierkegaard, el personaje prototípico que encarna a la perfección este modelo de fe es Abraham, «el caballero de la fe», tal y como nos lo presenta en Temor y temblor.

En la obra de Ibsen, «el caballero de la fe» kierkegaardiano viene representado por Brand, «hombre tenebroso», cuya vida es equiparable a la «oscuridad» de la «noche» ${ }^{17}$. Este personaje encarna a la perfección el modelo de fe que el pensador de Copenhague descubrió en Abraham: una fe ciega, irracional, determinada por una religión también irracional.

A la irracionalidad de la religión que nos presenta Kierkegaard se refiere

12. IChr, 76. KIERKEGAARD, Sygdomen til Doden, en Samlede Vaerker, cit., 1905, vol. XI, p. 209. En lo sucesivo citado con la abreviatura $S D$.

13. $K G, 189$.

14. $S D, 206$.

15. Eft, 326.

16. SD, 151. El problema razón-fe es típico del pensamiento nórdico, como también lo fue de la escolástica medieval; pero mientras que aquél (gestado en tierras de bruma) lo suele resolver a favor de la oscuridad de la fe, la escolástica (que se desarrolló en tierras de sol) se inclinó por la luz de la razón.

17. «Estrechada entre una y otra montaña, a la sombra de bóvedas y cumbres, apresada en la medianoche de la hendidura, mi vida desde este momento transcurrirá como una triste noche de otoño» (Brd, 77). 
Ibsen con distintos símbolos, los cuales albergan el significado común de la «oscuridad». El más significativo de ellos es el de la niebla: una «niebla espesa y pesada» (tagen ligger taet og tung), que al principio del drama envuelve la escena en la que se mueven los personajes, sobre todo Brand. Una niebla tan espesa que apenas deja ver el camino y, por tanto, en la que uno puede perderse. «Hay una milla hasta el próximo caserío, y la niebla es tan espesa, que puede cortarse con un cuchillo» ${ }^{18}$. «iVas a perderte! La niebla se está volviendo $\tan$ espesa, que apenas ve uno hasta donde llega el collado...» ${ }^{19}$. En este ambiente tan tenebroso de la religión, el creyente no puede ver nada mediante la luz de su razón. Vive totalmente a oscuras.

A este respecto, también es significativo el hecho de que la casa en la que viven Brand y su esposa Inés, tal y como nos lo muestra el tercer acto, esté ubicada en un lugar umbrío, adonde «el sol jamás llega» ${ }^{20}$.

Pero además de estas referencias indirectas al carácter irracional de la religión, aparecen en la obra de Ibsen otras alusiones directas a dicha característica, puestas en boca de Brand, Inés y el baile. El mismo Brand define a Cristo como el «enigma de los enigmas» (gaders gade) y, después de hacerse una serie de preguntas en relación a Dios, reconoce que no sabe ni puede saber nada acerca de él: « $Q Q u e ́$ puedo saber! Ahora se cierra todo, la oscuridad me ha envuelto de nuevo, no avizoro ninguna luz...» ${ }^{21}$. «Oscuridad» ésta que le resulta asfixiante, por eso quiere salir de ella y pide a Inés a voz en grito que lo ilumine: «iLuz, Inés! ¡Luz, si puedes! ¡Luz!» ${ }^{22}$. Cerca del final del acto cuarto, Inés, dolorida por las duras exigencias de Dios, exclama que en el Evangelio hay cosas incomprensibles, semejantes a una gran sima a la que no puede cruzar la luz de la razón. "¡A Ahora se abren ante mí, como una gran sima, aquellas palabras de la Sagrada Escritura que nunca llegaré a comprender a fondo!» ${ }^{23}$. Finalmente, el baile ve en la actitud de Brand (fiel seguidor de Dios) ante el honor que le quiere tributar el pueblo un comportamiento anormal, incomprensible, enigmático. «¿No está emocionado ante tamaño honor? ¡Para mí es usted un enigma!» ${ }^{24}$.

Pero frente a esta lúgubre población de conceptos tales como «niebla», «oscuridad», «profundidades», «tinieblas», «sombra», «medianoche», «noche de otoño», «bruma», «enigma»..., que de una forma directa o indirecta

\footnotetext{
18. Ibid., 5.

19. Ibid., 3.

20. Ibid., 81 .

21. Ibid., 156-7.

22. Ibid., 157.

23. Ibid., 162.

24. Ibid., 196.
} 
alude al carácter paradójico de la religión cristiana concebida por Kierkegaard, aparece otra población de conceptos de significado contrario, tales como «fuego», «aire y fuego diurno», «sol», «blancas llanuras», «mañana», «aurora», «resplandor matutino», «luz»... Mediante esta contraposición, Ibsen quiere dejar bien marcada la diferencia entre estas dos concepciones de la religión, así como resaltar el peculiar carácter de la primera frente a la segunda.

Tampoco falta en Ibsen la referencia a la inadecuación de la facultad de la razón para conectar con Dios, y a la consiguiente necesidad de recurrir al medio irracional de la fe (sentimiento, intuición, corazón, amor ciego...) para conseguir tamaño objetivo. Y lo mismo que Kierkegaard, el dramaturgo noruego compara la fe con la mujer: ambos ven la mujer como símbolo de la fe o amor irracional.

Según el escritor de Copenhague, el verdadero creyente cristiano se adhiere a Dios con una fe o amor ciego, el cual reúne los caracteres propios del amor romántico o primer amor: un amor quijotesco, imprudente, no racional; por eso apunta que la salvación viene de la mujer (símbolo de la irracionalidad, del amor romántico), mientras que la perdición procede del varón (símbolo de la razón, del amor racional) ${ }^{25}$. Como nos sugiere en el Diario, Kierkegaard había aprendido esta clase de amor («amable imprudencia») de su novia, Regina Olsen: vio en el amor que ésta le prodigaba el modelo de amor hacia Dios: un amor ciego, imprudente, incondicional, romántico... ${ }^{26}$.

Por lo que a esta cuestión se refiere, la relación de Kierkegaard con Regina y el significado que el amor de ésta tuvo para aquél, quedan reflejados por Ibsen en la relación de Brand con su esposa Inés y en la capacidad para ver «a ciegas» (iblinde) que aquél descubre en ésta ${ }^{27}$. Ibsen nos presenta a Inés como una mujer muy sensible e intuitiva: una mujer que no puede alegar razones con cordura; una mujer que se limita a sentir; una mujer que sabe sin comprender... ${ }^{28}$. Está dotada de una espléndida capacidad intuitiva que le permite captar en la oscuridad lo trascendente, lo misterioso, lo velado, a Dios, la voz de Éste... «Vislumbro (skimter) una tierra más grande... Veo jardines, estuarios. Brillan rayos de sol a través de la neblina. Veo relámpagos, rojos como llamas, que juguetean en torno a la cumbre velada por las nubes. Veo una

25. KierkegaARd, Enten-Eller, 2. Del, en Samlede Vaerker, cit., 1901, vol. II, p. 186. En lo sucesivo citado mediante la abreviatura $E E$-II.

26. Di, IX A 18; $\mathrm{X}^{1}$ A $374 ; \mathrm{X}^{5}$ A 149.

27. «Si Inés..., ella que ve a ciegas» (ser iblinde). (Brd, 157).

28. «¿Podré yo tal vez alegar razones con cordura? ¿Tai vez no viene la corriente del ánimo como un aroma en una ráfaga de aire? ¿De dónde ha venido? ¿Adónde va? Me basta con sentirlo (mig er nok, at jeg fortar den). Y sé, sin comprenderlo (jeg véd foruden viden)». (Brd, 133). 
vasta soledad desértica. (...). Y oigo voces que resuenan y voces que dicen: «éste es el momento en que te salvarás o te perderás...» ${ }^{29}$. «Aquí dentro siento (kende) fermentar fuerzas, siento ríos que se hinchan, veo nacer un día. El corazón (hjertet) se ensancha por demás como un mundo, en todos sentidos, y oigo voces que dicen: «iVas a poblar la tierra!» (...) Y adivino (aner) más que veo a Aquel que se eleva en las alturas; advierto cómo mira hacia abajo... Y oigo voces que cantan: «éste es el momento en que vas a crear y ser creada...» ${ }^{30}$. Contrariamente al maestro (representante de los funcionarios del Estado), el cual considera al «sentimiento" como algo indecoroso y vulgar ${ }^{31}$, Brand admira esta facultad en su esposa y se siente orgulloso de tenerla a su lado, o de identificarse con ella, pues Inés simboliza la fe irracional de Brand ${ }^{32}$.

\subsubsection{Ruptura con la razón práctica}

En Temor y temblor Kierkegaard nos advierte que, además de la ruptura general de la fe con la razón teórica o especulación teológica, a veces también puede acontecer otra ruptura del creyente con la razón práctica, con la ética. ruptura ésta que se efectúa en virtud de la religión, télos de aquélla; y que no equivale propiamente a una aniquilación de la ética, sino más bien a una «suspensión teleológica» (teleologisk Suspension) de la misma ${ }^{33}$.

$\mathrm{Si}$ es preciso, el individuo religioso debe «suspender» (o «superar», en el sentido hegeliano) el estadio ético de la existencia, porque tiene un télos superior fuera del mismo. Lo supremo no es la ética, sino la religión; por eso, cuando un determinado mandamiento divino entra en conflicto con un deber ético, éste último pierde vigencia en favor de la autoridad de aquél. Ante todo, el creyente debe atenerse a la ley religiosa, aunque esto suponga una infracción de las normas morales.

El pensador danés ilustra este caso de la «suspensión teleológica de la ética» recurriendo al pasaje veterotestamentario en el que se narra el sacrificio de Isaac por su padre Abraham. Abraham, al disponerse a cumplir el mandato divino de sacrificar a su único hijo, tiene que suspender momentáneamente la ética para obedecer a una autoridad superior, cual es la de la religión. «La historia de Abraham comporta... una suspensión teleológica de la ética» ${ }^{34}$. De

\footnotetext{
29. Ibid., 59.

30. Ibid., 60. Cfr. también ibid., 144.

31. Ibid., 185.

32. Ibid., 133-4.

33. $F B, 104$.

34. Ibid., 115 .
} 
esta forma, el patriarca rompe con la razón práctica; infringe una norma ética para cumplir un mandamiento divino, por lo que su comportamiento es calificado de «criminal» por la ética y de «bueno» por la religión.

Esta idea de la «suspensión teleológica de la ética», que Kierkegaard ejemplifica con el caso del sacrificio de Isaac, también queda reflejada en la obra de Ibsen, sobre todo al final del acto tercero ${ }^{35}$. Análogamente a como el viejo patriarca se dispuso a sacrificar a su hijo porque Dios se lo había pedido, Brand sacrificó su único hijo a la vocación religiosa que tenía: lo dejó morir para seguir cumpliendo en la comarca la misión ${ }^{36}$ de pastor que Dios le había encomendado.

Brand advierte a su esposa Inés que «el Señor puede atreverse a lo que antes se atrevió en el sacrificio de Isaac» ${ }^{37}$. Y poco después el médico pone a Brand ante la dura disyuntiva de abandonar inmediatamente el pueblo para salvar la vida del hijo enfermo o quedarse en el mismo, lo que traería consigo la muerte inmediata del niño ${ }^{38}$.

Lo «razonable», lo que en este caso impera la ética, es elegir lo primero: huir de aquel pueblo de clima insaludable para el niño, pues es deber ético de los padres velar por la salud de sus hijos. Al principio Brand está dispuesto a dejar el pueblo, por eso el médico le dice que obra como un padre ${ }^{39}$, es decir, como ordenan las leyes éticas. Pero después, tras los reproches que le hace el médico por ser «itan inflexible con el mundo y tan deferente consigo mismo! ${ }^{40}$, y tras recordarle un hombre del pueblo que ha sido enviado allí por Dios para cumplir una misión religiosa ${ }^{41}$, decide quedarse, con lo que accede a la exigencia divina de sacrificar a su hijo en favor de la vocación religiosa: « $i$ Dios! $i$ El holocausto (offer) que te has dignado exigir lo elevo hacia tu cielo!» ${ }^{42}$, exclama Inés. Brand «era pastor antes de ser padre» y creía «ciegamente en la llamada del Señor» ${ }^{43}$, lo que significa que la religión está por encima de la ética y que, como en este caso ambas dictan órdenes contradictorias, hay que obedecer a la que tiene mayor autoridad.

35. Brd, 113-124.

36. «...mi misión, a tan alto precio comprada». (Ibid., 128).

37. Ibid., 147.

38. Ibid., 113.

39. «Obras como debe obrar un padre. No creas que censuro lo que haces». (Ibid., 115).

40. Ibid., 114.

41. «iCuántas veces nos has dicho que Dios mismo te ha enviado a la lucha, que entre nosotros está en tu hogar, que aquí ha de llevarse a cabo tu guerra, que ningún hombre osaría hacer fracasar tu misión, que hay que pelear y nunca retirarse! ¡Y vocación, la tienes! ( . . 7. Tú me has sacado del abismo. ;A ver si ahora te atreves a soltarme! No puedes. Me aferro a ti. (...). Mi pastor no nos abandonará a Dios y a mí». (Ibid., 117).

42. Ibid., 124.

43. Ibid., 122-3. 
Así, pues, la decisión de quedarse en el pueblo adoptada por Brand supuso la infracción de una ley ética; decisión ésta que (lo mismo que la de Abraham) es considerada por la religión como un acto «bueno», mientras que la ética la ve como un «crimen», de ahí que el baile afirme respecto a Brand: «icasi mató a su hijo!» ${ }^{44}$.

\subsubsection{Elección y riesgo}

Dentro de la filosofía de Kierkegaard en general y, en particular, dentro de esta concepción irracional de la religión, es nuclear la categoría de elección o decisión. Categoría ésta a la que acompañan las de «individuo concreto» y «angustia» como presupuestos; y las de «pecado», «arrepentimiento», «responsabilidad» $\mathrm{y}$ «riesgo» como consecuencias.

Según los hegelianos daneses del ámbito de la religión, la fe aparece espontáneamente en el hombre, lo mismo que los dientes, la barba... ${ }^{45}$. De este modo, el tránsito a la existencia religiosa constituye un paso automático, impregnado de necesidad. Está determinado por una serie de causas, incluso causas materiales.

A esta última idea apuntan las palabras que el deán dice a Brand, tras haber afirmado éste que el nuevo edificio de la iglesia debe cobijar «un alma renacida» y «un espíritu purificado»: «Esas cosas vendrán por sí solas. Una bóveda artesonada, tan grandiosa y bella, un lugar tan luminoso, traerán consigo la limpieza de las gentes. Y esta hermosa resonancia, que convierte en dos cada palabra del pastor, aumentará la fe de los fieles un ciento por ciento en cada alma. Sin duda, son estos resultados que... ${ }^{46}$.

De esto se deduce que todos los hombres llegan a ser cristianos sin más, por las buenas, sin hacer el más mínimo esfuerzo. «...esa cristiandad en la cual millones y millones de hombres son cristianos sin más, de suerte que no tiene nada de extraño que en sus confines haya tantos cristianos como hombres» ${ }^{47}$. En la cristiandad, la religiosidad es un bien que se distribuye al por mayor entre todos los hombres ${ }^{48}$; 0 , como dice Brand: «hoy lo han vendido por lotes; de tal suerte considera la estirpe a Dios» ${ }^{49}$.

Contrariamente a los hegelianos, Kierkegaard sostiene que el tránsito al estadio religioso de la existencia no es un paso mecánico, sino un «salto»

\footnotetext{
44. Ibid., 237.

45. $S D, 170$.

46. Brd, 196.

47. $S D, 212$

48. Eft, 105 .

49. Brd, 26.
} 
(Spring) que se efectúa en virtud de una libre elección (Valg). El hombre se encuentra ante una alternativa (Enten-Eller) con la obligación de elegir uno de los dos polos; «tiene que elegir entre Dios y las riquezas», entre Dios y el mundo», entre un modo de existencia religiosa y un modo de vida estética, entre someterse a las exigencias divinas y dar rienda suelta a la energía de sus instintos egoístas... ${ }^{50}$. Y el punto del tiempo en el que el individuo da el salto de la fe, decidiéndose por la forma de existencia religiosa, constituye un momento especial, distinto de otros momentos anónimos de la vida: es «el momento» o «el instante» (Oieblikket) ${ }^{51}$.

Pero una vez efectuada esta «primera elección» o «elección originaria» que introduce al individuo en el ámbito de la religión, posteriormente el creyente tiene que seguir realizando constantemente dentro de esta esfera elecciones subsiguientes entre el bien y el mal, entre cumplir o infringir la ley religiosa ${ }^{52}$. Por consiguiente, el individuo religioso siempre tiene ante sí distintas posibilidades alternativas, que lo fuerzan a una elección.

De la importancia que para el pensador danés tiene la categoría de la «elección», nos da buena cuenta Ibsen en su Brand, pues aquél es uno de los conceptos que irrumpen con más frecuencia e insistencia a lo largo de la obra.

Primero es Inés quien tiene que elegir entre seguir a Ejnar (esteta) o a Brand (individuo religioso): entre la vida estética o la existencia religiosa,'entre el mundo o Dios... Tanto Ejnar como Brand plantean a Inés la alternativa de estos dos modos de vida contrapuestos; la ponen ante un cruce del que parten dos caminos hacia metas muy diferentes. Aquél, tentándola a que se decida por lo más cómodo y atractivo, le grita primero: «¡Escoge (vaelg) entre las claras llanuras y el lúgubre callejón del dolor!» ${ }^{53}$; y después: «¡Elige (vaelg) entre la tempestad y la calma! La elección (valget) entre partir o quedarse lo es entre la alegría y el pesar, entre la noche y la mañana, ; entre la muerte y la vida!» ${ }^{54}$; y le recuerda el viejo proverbio: «¡fácil de levantar, pesado de llevar!» ${ }^{55}$. En cambio Brand, más neutral, simplemente le dice: «elige. Estás en el cruce (skille) de dos caminos» ${ }^{56}$. En este caso se trata de la «primera

50. KierkegaARd, Opbyggelige Taler i forskellig Aand, en Samlede Vaerker, cit., 1903, vol. VIII, pp. 289-291. (En adelante citado mediante la abreviatura OTfA). De ahí que Kierkegaard afirme varias veces que no es cristiano, sino que deviene cristiano: «no me llamo a mí mismo cristiano» (Id., Bladartikler 1854-55, en Samlede Vaerker, cit., 1906, vol. XIV, pp. 189, 2823); o en palabras de Brand: «apenas sé si soy cristiano». (Brd, 22).

51. KierkegaARD, Philosophiske Smuler, en Samlede Vaerker, cit., 1902, vol. IV, pp. 183, 188-190. EE-II, 185. KG, 175.

52. $E E-I I, 196$.

53. Brd, 75.

54. Ibid., 77-8.

55. Ibid., 75 .

56. Ibid., 77 . 
elección»; la cual introduce a Inés en el ámbito de la religión. Y el punto del tiempo en que se hace esta elección tan decisiva es, como nos recuerda la misma Inés, «el momento» por excelencia: «éste es el momento en que te salvarás o te perderás. Lleva a cabo tu hazaña...» ${ }^{57}$.

Después son Brand e Inés quienes, tras conocer el diagnóstico hecho por el médico sobre la enfermedad del niño y el peligro que la vida de éste corre si siguen viviendo en aquel pueblo, tienen que decidir si se van o se quedan allí ${ }^{58}$. En este caso, así como en los otros dos que señalaremos a continuación, ya no se trata de la «primera elección», sino de una «elección subsiguiente», pues tanto Brand como Inés ya están dentro de la esfera religiosa.

En tercer lugar, le toca de nuevo a Inés tener que elegir entre desprenderse de las ropas del niño muerto, exigidas por la gitana, o seguir guardándolas para sí con tanto cuidado ${ }^{59}$.

En cuarto lugar, es el propio Brand quien debe elegir entre aceptar con resignación la muerte de su esposa Inés o no aceptarla. Después de haber renunciado Inés a lo último que le quedaba del niño (la ropa), le dice a Brand lo que éste le había manifestado a ella antes: «ahora eres tú quien se encuentra en el valle de la opción. (...). Escoge: estás en el cruce de dos caminos. (...). ¡Escoge! ¡Estás en el cruce de dos caminos!» ${ }^{60}$.

Finalmente, ascendiendo la cuesta detrás de Brand, es el pueblo el que tiene que elegir ${ }^{61}$ entre la propuesta de aquél, por una parte, y la del deán y el baile, por otra: entre seguir ascendiendo con Brand «;a las alturas!» o descender con el baile y el deán «ia nuestras casas!»; es decir, entre el duro cristianismo de Brand y la suave religión de la Iglesia establecida, entre el cristianismo auténtico y el inauténtico, entre el cristianismo y la cristiandad (o paganismo) ${ }^{62}$. Por tanto, aquí también se trata de la «primera elección»: de elegir entre entrar en el cristianismo o quedar fuera de él.

Al principio de este apartado apuntábamos que la categoría de «elección» presupone la de «individuo concreto». Esto significa que el acto de elección es un acto personal e intransferible, llevado a cabo por un individuo concreto. Cada individuo tiene que elegir por sí mismo el tipo de vida que va a llevar, sin poder cargar a otro con el peso de semejante tarea. «Seguir (a Cristo) significa... estar obligado a elegir por uno mismo... ¡Caminar solo! Precisamente así, pues no hay nadie... que pueda elegir por ti...» ${ }^{63}$.

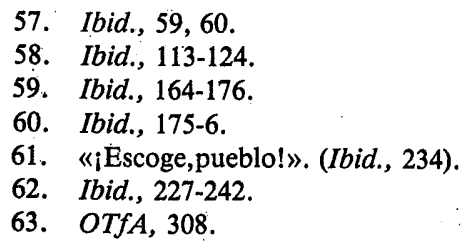


Esta idea de la individualidad, que tanto resalta Kierkegaard, está en contradicción con el sistema hegeliano, en el que se da más importancia al Todo general supraindividual que al individuo particular ${ }^{64}$. Tanto Hegel como los hegelianos daneses del ámbito de la religión disuelven el individuo en el Todo del sistema, del Estado y de la Iglesia, donde el hombre queda convertido en un mero elemento anónimo, intercambiable con cualquiera de sus congéneres.

Esta contraposición del individuo concreto kierkegaardiano ${ }^{65} \mathrm{y}$ del todo estatal y eclesiástico hegeliano la pone de manifiesto Ibsen por medio del deán, el cual le reprocha a Brand (Kierkegaard) su excesiva atención a «las necesidades de cada uno», el «ocuparse de cada alma», en vez de atender a «la parroquia entera». Contrariamente a Brand, el deán quiere «que a todos se los pese en bloque y mida a cada cual por el mismo rasero»; sostiene que «cada cual debe... confundirse con la masa». Lo mismo que al Estado, le encanta «el tesoro de la igualdad» (ligheds-skatten), el que cada individuo sea meramente «un eslabón de la Iglesia», y no «una personalidad», como pretende Brand ${ }^{66}$. A este respecto, también es muy significativo que el deán emplee en repetidas ocasiones los términos «ovejas» y «rebaño» para referirse a los feligreses ${ }^{67}$. El primero apunta al carácter amorfo y anónimo del creyente en la Iglesia establecida, el cual se funde y confunde con la masa. Y el segundo significa la primacía del Todo global sobre el individuo particular; Todo éste que se deja llevar, en vez de ser cada individuo el que toma las riendas de su destino.

El otro presupuesto de la elección, de la elección de la religión, es la «angustia». Contrariamente a los hegelianos y a la mayoría de los filósofos modernos, Kierkegaard sostiene que el hombre no asciende a la fe por vía racional, sino a través de la experiencia existencial de la angustia (Angest). La angustia abre al hombre a lä fe al mostrar a éste su propia miseria (su «nada») y al avivar en él consiguientemente la sed de redención ${ }^{68}$.

Aunque en la obra de Ibsen aparece numerosas veces el término «angustia» (angst), no siempre tiene este significado kierkegaardiano que acabamos de insinuar: la angustia como sentimiento doloroso de la nulidad de mi ser frente a la grandeza de Dios; sentimiento éste que me impulsa a contactar con

64. $S D, 156,195,228-9$.

65. Semejante categoría de la filosofía de Kierkegaard tiene su correlación real en la vida de éste. Como todos sabemos, Kierkegaard era un hombre extraño, que vivió muy apartado de la sociedad, en estricta soledad. Ibsen nos recuerda este rasgo de la personalidad de Kierkegaard así: EJ. NAR, «iBien hallado! ¡Mírame! Sí, eres el mismo, el que siempre bastaba a sí propio, a quien nunca pudo el juego incluir en el retozón tropel de camaradas». BRAND, «Era un extraño entre vosotros. (...) todos los del sur erais de otra manera que yo...» Brd, 19).

66. Ibid., 119-208.

67. Ibid., 192, 197, 223, 226, 232, 238.

68. $B A, 422$ y $425 . D i, \mathrm{X}^{1} \mathrm{~A} 463$. 
Aquél. No obstante, de algunas de las afirmaciones que apuntan a dicha categoría, parece desprenderse que el estado propicio del hombre para relacionarse con Dios es el de la angustia. Tal es el caso de las siguientes: «A todos vuestros padrenuestros les faltan las alas de la voluntad, el clamor de la angustia, necesarios para llegar hasta el cielo» ${ }^{69}$. «Es necesario querer la muerte en la cruz..., quererla en medio de las angustias del espíritu» ${ }^{70}$. «...en los peores días de angustia, en la gran hora del espanto, de la pena... ¿No recé a mi vez?» ${ }^{71}$.

En cuanto a las consecuencias de la «elección» tenemos lo siguiente. Por el hecho de que el individuo tenga libertad de elección, puede elegir lo malo (pecado) es responsable de lo elegido y tiene la oportunidad de arrepentirse: pecado, responsabilidad y arrepentimiento son tres categorías importantes de la concepción kierkegaardiana de la religión, que de algún modo también se traslucen en la obra de Ibsen.

Kierkegaard trató estos temas sobre todo en dos de sus obras más importantes: El concepto de la angustia (un mero análisis psicológico en la dirección del problema dogmático del pecado original) y La enfermedad mortal o de la desesperación y el pecado. En él, estas tres categorías van unidas al individuo concreto: sólo el individuo concreto puede ser sujeto del pecado y, consiguientemente, del arrepentimiento y de la responsabilidad del mismo ante Dios: «el concepto de pecado y de culpa pone cabalmente al individuo en cuanto individuo» ${ }^{72}$; "sólo arrepintiéndose se es concreto» ${ }^{73}$; «cada hombre, en cuanto individuo, debe rendir cuentas a Dios...» ${ }^{74}$.

Ibsen se refiere a ellos en varias ocasiones y a través de distintos personajes. El problema del pecado y del arrepentimiento aparece planteado por vez primera en el pasaje que nos relata el caso del padre que, compungido por el sufrimiento ajeno, mató a su hijo agonizante; y que se arrepiente inmediatamente de su acto criminal, según nos cuenta la esposa del mismo: «Mi marido... Los tres pequeñuelos, hambrientos, y la casa vacía... El chiquitín luchaba a duras penas con la muerte... Eso le partía el alma... ¡Puso las manos sobre el niño! (...). ¡En el mismo instante vio lo atroz de su acción! Su arrepentimiento crecía como un torrente» ${ }^{75}$.

Después es Inés quien, al comunicarnos una intuición, nos advierte de la

69. Brd, 30.

70. Ibid., 89-90.

71. Ibid., 156-7.

72. $B A, 367$. «La categoría del pecado es la categoría de la individualidad». $(S D, 228)$.

73. $E E-I I, 222$.

74. OTfA, 220 .

75. Brd, $43-4$. 
responsabilidad ligada al acto de la heroica elección: «lleva a cabo tu hazaña, llena de responsabilidad» ${ }^{76}$.

Quizás las referencias más importantes a estos temas sean las que aparecen en torno a la figura de la madre de Brand, una anciana moribunda muy apegada a las riquezas materiales. Según el hijo, el pecado de ésta consiste en el excesivo apego a los bienes terrenales y, por lo tanto, en haber malgastado el préstamo del alma que le hizo Dios: en haber cubierto de moho y fango la imagen de Dios que recibió de éste al nacer ${ }^{77}$. Brand le advierte que este pecado sólo se puede borrar mediante el arrepentimiento, y que es ella misma la que tiene que responder de dicha falta ante Dios. "Advierte bien lo que te digo. (...) de tu pecado has de responder tú misma. (...). Pero el pecado está en haberlo derrochado. ¡Y para eso no hay más que el arrepentimiento... o la muerte!» ${ }^{78}$. Brand espera con impaciencia el momento del arrepentimiento de su madre: «tu hijo... esperará el mensaje de la hora de tu arrepentimiento» ${ }^{79}$; arrepentimiento que tiene que realizar ella misma: «si ella no se arrepiente de su pecado...» ${ }^{80}$. Así, pues, Ibsen refleja perfectamente la conexión que Kierkegaard había establecido entre estas tres categorías religiosas y el individuo concreto.

Pero el problema de la culpa y de la responsabilidad tiene otra dimensión, a la que Ibsen quizás da más importancia de la que en realidad le confirió Kierkegaard. Nos referimos al tema de la herencia de la culpa y de la consiguiente responsabilidad, según el cual las personas no sólo son responsables de sus propias faltas sino también de las de sus mayores o antepesados.

Como nos refiere en el Diario ${ }^{81}$, Kierkegaard creía que toda su familia era responsable de faltas cometidas por el padre: la blasfemia que pronunció de niño contra Dios cuando, azotado por el hambre, pastoreaba un rebaño de ovejas en los campos de Jutlandia; y las relaciones incestuosas que mantuvo con una pariente, entonces criada y después su segunda esposa. Estaba convencido de que sobre toda la familia se cernía una terrible tragedia como castigo, y que él y su anciano padre estaban condenados por Dios a contemplar hasta el final, como un crucifijo sobre una tumba, la pronta desaparición de los distintos miembros de la familia, para de este modo expiar las faltas cometidas por el progenitor; desaparición ésta que, de hecho, se estaba produciendo poco a poco.

76. Ibid., 59,60. También al final del acto cuarto Inés se arrepiente de la mentira que le había dicho a Brand, relacionada con el donativo de la ropa del niño muerto a la gitana. (Ibid., 173).

77. Ibid., 69.

78. Ibid., 70 .

79. Ibid., 73.

80. Ibid., 80.

81. Di, II A 805; VII ${ }^{1}$ A 5 . 
En la obra de Ibsen aparecen varios textos y afirmaciones sueltas que apuntan a este problema. Dos de ellos son los más amplios e importantes. El primero está relacionado con el caso de aquel padre que acabó de matar al menor de sus hijos, el cual agonizaba víctima del hambre. Este acto tan atroz, realizado por el padre, dejará un estigma imborrable en las almas de los otros dos hijos que lo contemplaron, los cuales nunca podrán abandonar ese recuerdo detestable; la vida de ellos quedará marcada para siempre por la amargura de semejante acción. Y esto ¿por qué? «He aquí la vacua respuesta abismática: jeran hijos de su padre! (...). ¿Desde cuándo cae el peso de la responsabilidad sobre la herencia de los descendientes?» ${ }^{82}$.

El otro texto tiene que ver con los yerros de la madre de Brand, y la repercusión de los mismos sobre éste y sobre el hijo de Brand. Brand debe limpiar la imagen de Dios manchada por la avaricia y egoísmo de su madre; tiene que saldar la deuda contraída por ésta con Dios, porque «es deber del hijo cumplir con todos los acreedores que rodeen la tumba de su madre»" ${ }^{83}$. Deuda ésta que Brand salda con la muerte de su hijo. Dios dio a Brand un hijo en préstamo; se lo dio para quitárselo más tarde, y de esta forma expiar las culpas de la anciana madre con respecto a Él. «¡Hijito mío! ¡Cordero sin mancha! Tú has caído por culpa de mi madre. Un alma pródiga ha traído el mensaje de Aquél... Esta alma pródiga existe, existe porque el alma de mi madre se extravió. Tal destino da el Señor a la cosecha del pecado, para sustentar el equilibrio y la imparcialidad. Así, lanza desde las alturas el castigo hasta la tercera generación» ${ }^{84}$.

Hemos apuntado que el riesgo es otra consecuencia de la «elección». Ahora concretamos un poco más y afirmamos que es una consecuencia de la elección de la religión. Por consiguiente, la fe implica un riesgo para el creyente. ¿Por qué?

Anteriormente hemos visto que, según Kierkegaard, la religión es de naturaleza irracional, paradójica. Esto significa que su contenido es indemostrable $\mathrm{y}$, por tanto, incierto e inseguro. «El carácter paradójico de la verdad es su incertidumbre objetiva» ${ }^{85}$.

Ahora bien, si la religión pertenece al terreno de la incertidumbre objetiva, quiere decirse que la elección y asimilación existente de la misma implica un riesgo (Risico) para el creyente: el riesgo de asentar la propia vida sobre una realidad insegura o posible irrealidad y, consiguientemente, el riesgo de equivocarse completamente y perderlo todo. «Creer es arriesgarse tan decidi-

82. Brd, 52 .

83. Ibid., 69,

84. Ibid., 156. Cfr. también Ibid., 214, 260.

85. Eft, 171 . 
damente como le sea posible hacerlo a un hombre» ${ }^{86}$. El creyente es un aventurero que, en su heroico acto de fe, se arriesga a existir en lo objetivamente inseguro y, por tanto, a perder su vida. Así, pues, el riesgo constituye otra condición esencial de la fe: «sin riesgo no hay fe» ${ }^{87}$.

Kierkegaard ilustra esta idea del riesgo de la fe con dos ejemplos. Uno de ellos, al que hace referencia innumerables veces en diferentes escritos, es el símil del nadador: se trata de un hombre que, sin apenas saber nadar, es arrojado en medio del mar sobre una profundidad de 70.000 brazas de agua, con lo que se encuentra en peligro de hundirse y ahogarse. El otro símil es el del marinero en cuya barca empieza a entrar agua por una rendija y va hundiéndose poco a poco ${ }^{88}$.

También Ibsen emplea dos imágenes para expresar la idea del riesgo de la fe, una de las cuales aparece al principio del primer acto y la otra al principio del segundo.

La primera imagen ${ }^{89}$ nos presenta a Brand (símbolo del caballero de la fe) moviéndose sobre un piso inseguro, en constante peligro de hundirse y perder la vida. El pastor camina sobre la nieve de las mesetas montañosas, atraviesa «charcas heladas», anda «sobre las aguas»... Por debajo del suelo que pisa corre «un arroyo»; hay «hoyos», «grietas», el enorme desnivel de «una cascada»...; en definitiva: se abre «un abismo sin fondo». El campesino (hombre muy prudente) y su hijo no dejan de advertirle a voz en grito del peligro de hundimiento y del riesgo a que está exponiendo su vida: «¡Para, hombre! ¡Por los clavos de Cristo! ¡El hielo es aquí tan delgado! ¡No pises fuerte! (...). Se ha abierto cauce un arroyo por debajo. Hay un abismo sin fondo... ¡Nos tragará a ti y a nosotros! (...). Ya ves: aquí está socavado y el piso es quebradizo. ¡Para, hombre! ¡Te juegas la vida! (...) ¡Te va la vida en ello!» ${ }^{90}$. Pero Brand, con la terquedad y tenacidad que lo caracterizan, no les hace caso y sigue adelante, pues cree que ése es su deber: dice estar cumpliendo «el mandato del gran ser» ${ }^{91}$.

La segunda imagen nos describe la hazaña que realizó Brand al cruzar en una lancha el proceloso fjord para salvar el alma irresoluta de un pecador

86. KieRKEGAARD, Bladartikler..., cit., p. 229.

87. Eft, 170 y 176 .

88. KIERKEGAARD, Stadier paa Livets Vei, en Samlede Vaerker, cit., 1902, vol. VI, pp. 4145, 437-8. Eft, 170, 189 (nota), 195 y 246.

89. El drama de Ibsen se desarrolla en un escenario típico de Noruega, país glacial, tenebroso, montañoso, vecino del mar, con un litoral muy accidentado por los numerosos fjords y altos acantalidados desde los cuales se precipitan cascadas entre nubes de vapor. Ibsen se sirve del símbolo de este paisaje natural de su tierra natal para expresar ideas religiosas.

90. Brd, 4-6.

91. Ibid., 4. «Tengo que seguir adelante» (Ibidem.). 
moribundo ${ }^{92}$. Una mujer llega pidiendo «jsocorro!» a la muchedumbre aglomerada a la vera del fjord. Viene en busca de un pastor, que vaya al otro lado del fjord a salvar el alma de su marido, pecador al borde de la muerte. Se desencadena una tormenta horrorosa. El mar se enfurece, agitado por un oleaje estrepitoso. Cuando «ila tempestad arrecia!», cuando «ilas olas se estrellan contra las rocas y bajíos!» y «itodo hierve y arroja humo!», Brand se dispone a cruzarlo en lancha, pues no hay camino transitable bordeando el fjord hacia la meta que se desea alcanzar. La multitud se horroriza, y le suplica que se quede, que no arriesgue su vida poniéndola a merced de las aguas indómitas. Mas el pastor no hace caso. Pide que le acompañe alguien ${ }^{93}$ «en el viaje de salvación», pero nadie (ni siquiera la mujer afectada) se atreve: «iSoy joven y amo mi vida! ¡No puedo! (...) ¡No me atrevo!», exclama Ejnar. Por fin, se arriesga Inés, cuya decisión aterroriza a las mujeres que la contemplan, y al mismo Ejnar, quien le grita: «iSalva tu vida!».

Además de estos dos cuadros, en los cuales aparecen agrupados diversos conceptos que expresan simbólicamente la inseguridad característica de la vida del creyente, y el consiguiente riesgo que entraña la fe para la existencia de aquél, a lo largo de la obra encontramos dispersos otros conceptos y expresiones que también apuntan indirectamente a esta nota de la concepción kierkegaardiana de la religión:

$\mathrm{Al}$ riesgo de la fe se refiere la advertencia de peligro que hace Brand a Ejnar e Inés cuando éstos se aproximan al borde de un precipicio: «iAlto, alto! ¡Más allá hay un precipicio! (...) ¡Salvaos a tiempo! ¡Estáis sobre el techo socavado del glaciar que avanza colgando al costado del cantil» ${ }^{94}$.

Se refieren las palabras dirigidas a Brand por un hombre, testigo de la hazaña de aquél sobre las tempestuosas aguas del fjord: «...la gran hazaña. Cuando aullaba la tempestad y azotaban las olas, cuando te lanzaste contra viento y marea, cuando por un alma irresoluta de pecador arriesgaste la vida sobre un madero..." ${ }^{95}$.

Se refieren las súplicas que a Brand hace la madre, tras conocer ésta la escalofriante noticia de la aventura de su hijo al lanzarse al proceloso mar: «Pero isalva la vida por mí! (...) ¡Hasta muy lejos corren rumores de lo que has hecho, y eso me llena de espanto! ¡Lanzarte al fjord hoy! ¡Podrías haber perdido lo que por mí debieras conservar! (...) ¡Ten cuidado de tu vida! ¡No la entregues jamás!» ${ }^{96}$.

\footnotetext{
92. Ibid., 43-51.

93. «ßBien! ¡Venga quien esté dispuesto a arriesgar su vida!». (Ibid. 45).

94. Ibid., 13.

95. Ibid., 57.

96. Ibid., 63.
} 
Se refieren las palabras del propio Brand sobre la ubicación de su hogar entre dos abismos, con todo el peligro y riesgo que ello supone para su vida: «Ahora me encuentro donde anoche, envuelto en brumas mucho antes que decline el día. Estoy entre el despeñadero y el acantilado...; pero estoy sobre el suelo de mi hogar» ${ }^{97}$.

Con esta población de conceptos y expresiones que hemos entrecomillado ${ }^{98}$, Ibsen simboliza el riesgo a que está expuesta la vida del creyente: la vida del que, como Brand, camina o navega sobre la insegura superficie de la fe. Recogiendo la idea de Kierkegaard, Ibsen nos viene a decir con estas imágenes que la elección de la fe es algo semejante a lanzarse a un mar revuelto por la tempestad sin apenas saber nadar; o a ponerse a caminar sobre una superficie de hielo delgada y frágil, bajo la que se abre una profundidad abismática. Ambas imágenes expresan las ideas de inseguridad y riesgo inherentes a la fe.

Por tanto, «fe» es sinónima de inseguridad y riesgo, mientras que «razón» equivale a certidumbre y seguridad. La contraposición de ambas categorías queda insinuada en la pregunta que Brand (caballero de la fe) hace al baile (funcionario público: hombre perspicaz) y en la respuesta que éste le da: Brand: «¿Lo cree?» El baile: «¿Que si lo creo? No; estoy seguro» ${ }^{99}$.

El camino de la salvación no va a través de la tierra firme y segura de la razón, sino sobre la superficie insegura de la fe: es el riesgo de la fe. Este último es el camino que sigue Brand cuando se decide a cruzar el mar para salvar el alma del hombre pecador, pues no había un sendero por la tierra firme bordeando el fjord que llevara a la meta ${ }^{100}$. Con lo cual, la tarea de la salvación implica el riesgo de la perdición: para intentar salvar el alma hay que arriesgarse a perderlo todo.

A este respecto, es muy significativa la contraposición que establece Ibsen al principio de la obra entre las figuras de Brand (símbolo de la fe) y el campesino (símbolo de la razón). Podemos decir que Brand es un hombre «de mar», pues nació y se crió «en un cabo a la orilla de las aguas» ${ }^{101}$. Su vida está ligada al mar, al agua, medio éste que supone un peligro de inundación para los habitantes de la costa y un peligro de hundimiento para el marinero. Éste vive y trabaja sobre una superficie insegura, en constante peligro de hundimiento, 80).

97. Ibid., 74. «Nuestro hogar no es acogedor, entre el despeñadero y el acantilado». Ibid.,

98. Cascada, nieve, hielo, abismo, fjord, precipicio, glaciar, cantil, despeñadero, acantilado, etc.

99. Brd, 100 .

100. Ibid., 44.

101. Ibid., 19. 
así como los habitantes costeros padecen la continua amenaza de las inundaciones ${ }^{102}$. Por el contrario, el campesino es un hombre «de tierra», del interior. Vive y trabaja sobre tierra firme (fastland), sin peligro de hundirse y perder la vida. Así, pues, la contraposición de Brand (marino) y el campesino equivale a la del mar y la tierra, la fe y la razón, inseguridad y seguridad.

Por la absoluta negación de la razón y por la entrega incondicional a una realidad insegura, con todo el riesgo que ello supone para la vida, el Brand de Ibsen, lo mismo que «el caballero de la fe» kierkegaardiano, es un «loco» (afsindig, Nar) ${ }^{103}$ : un loco que, con los ojos de la razón cerrados, se arriesga a lanzarse al inseguro mar de la religión. De ello nos cerciora el campesino que, al ver a Brand caminando sobre el piso inseguro de las mesetas montañosas nevadas, exclama: «iestá loco!» ${ }^{104}$. Y la madre de Brand cuando, por haberse lanzado éste al fjord en medio de la tempestad, le increpa: «ihijo, estás $10 c 0 ! »{ }^{105}$. Y el sacristán cuando, tras advertir el absurdo comportamiento de Brand y lo irracional de la doctrina que predica al pueblo, aconseja a las gentes que siguen al pastor subiendo la montaña: «¡Dejad a ese loco!» ${ }^{106}$.

Como resumen y conclusión de todo este apartado tercero queremos anotar lo siguiente. Desde el carácter irracional del cristianismo, para Kierkegaard, tal como se manifiesta en la obra de Ibsen, el individuo auténtico queda definido por el coraje. Es auténtico hombre el que tiene el coraje de arriesgarlo todo para intentar salvar el alma: el que tiene el valor (mod) de dar el arriesgado salto de la fe. Así nos lo da a entender un personaje anónimo del drama, tras contemplar la aventura de Brand surcando con la barca las aguas

102. Tanto Kierkegaard como Ibsen se sirvieron de la imagen del agua/mar para simbolizar la idea del riesgo de la fe. Y es normal que lo hayan hecho, si tenemos en cuenta la importancia y marcada presencia de dicho medio en los países escandinavos. Estos países «conviven» con el mar: el agua del mar baña sus extensas costas, e incluso penetra hasta las entrañas mismas de la tierra a través de los numerosos fjords; de ahí que muchos de los habitantes sean marineros, o navegantes, como lo fueron sus antepasados los vikingos. Otro pensador, el cual vivió al lado del mar Egeo en los albores de la historia de la filosofía, también se sirvió del «agua» para explicar la realidad. Pero mientras que éste (habitante del soleado sur y, por tanto, hombre optimista) vio el agua como principio de la «vida» de todas las cosas, tanto Kierkegaard como Ibsen (habitantes del tenebroso Norte y, por consiguiente, hombres pesimistas) la ven como peligro de muerte, de hundimiento... p. 218.

103. FB, 124. Di, $\mathrm{X}^{1}$ A 133. IChr, 43. KG, 189. KIERKEGAARd, Philosphiske Smuler; cit.,

104. Brd, 6.

105. Ibid., 64.

106. Ibid., 237. 
del fjord enfurecido por la tormenta. «Sí. Lo que es... eso bien se ha visto: un hombre. Hay en él valor, fuerza y tenacidad» ${ }^{107}$. Y a este modelo de hombre también hace referencia el mismo Brand posteriormente, al principio del acto cuarto, empleando para ello una imagen marítima análoga a la anterior. «¡Ah! ¡Ahí fuera me sentía yo un hombre! Las olas cubrían los escollos, la gaviota se callaba con el espanto de la tempestad, el granizo azotaba mi propia barca. Estábamos en medio del fjord. Bullía el agua. Mástil y aparejo golpeaban con brío. El viento se llevó la vela, hecha jirones, allá lejos, entre los espumarajos del mar revuelto. Rechinaban todos los remaches de la embarcación... ¡Oh! Entonces me sentía crecer junto al timón» ${ }^{108}$.

\section{De la RELIGIÓN ESTÉtiCA A LA ASCÉTICA}

\subsection{Religión estética}

Los representantes oficiales de la Iglesia protestante danesa de la primera mitad del siglo XIX, acaudillados por el obispo Mynster y luego por su sucesor Martensen, e inspirándose en el principio filosófico hegeliano de «la identidad del pensar y del ser» (que viene a ser equivalente al cartesiano «cogito ergo sum») ${ }^{1}$, concebían la religión cristiana como una «representación» conceptual de Dios: como mera doctrina. Daban menos importancia a la persona de Cristo que a su doctrina o enseñanza. «En toda la modernidad... se ha eliminado totalmente a Cristo, arrojado fuera, y se ha tomado su doctrina (Laehre), considerándole a él en definitiva casi como se considera a un anónimo: la enseñanza es lo principal, lo es todo» ${ }^{2}$. De esta forma, reducen el «ser» cristiano al «pensar» sobre el cristianismo, lo que equivale a profesar una fe sin obras. La «cultura teológica» es lo que define a un cristiano: el que cree, explica o predica la verdad revelada en el Evangelio ya es cristiano, aunque luego no exprese en su vida personal mediante las obras lo allí expuesto mediante conceptos.

Semejante transformación de la religión cristiana en una enseñanza objetiva, orientada hacia un público «inculto» y ávido de «saber», trae consigo dos consecuencias. Lo primera de ellas es la relevancia que adquiere la «predicación cristiana» (christelig Praediken) dentro de los actos litúrgicos; predica-

107. Ibid., 51.

108. Ibid., 128. «En el fondo, la pasión es lo esencial, el verdadero dinamómetro del hombre». ( $D i$, III A 185).

1. $S D, 204$ у 229.

2. IChr, 115-6. 
ción ésta en la que lo único.importante es la corrección y la belleza literaria del mismo discurso ${ }^{3}$.

La segunda consecuencia es la concepción de los clérigos como «profesores de cristianismo» (Laerere i Christendom), y, por tanto, como «funcionarios reales» (kongelige Embedsmaend) pagados por el Estado. El Estado ha hecho un «contrato» (har contraheret) con la Iglesia, en virtud del cual el cristianismo es «patrocinado por el Estado» y se convierte en una «religión del Estado». Por tanto, aquélla se pone al servicio de éste: es su instrumento.

Dentro de esta concepción «teórica» de la religión, resalta el afán de lucro por el que se mueven los sacerdotes, la restricción de la misma a los domingos ${ }^{4} \mathrm{y}$ el carácter principal y exageradamente festivo de ciertos actos rituales. Los clérigos, en tanto que funcionarios del Estado, tienen «intereses temporales» análogos a los de los «comerciantes», con lo que convierten la casa de Dios en una «tienda» y, consiguientemente, identifican al cristianismo con «un reino de este mundo». Por lo general, la religión se reduce al rutinario culto de los domingos, quedando prácticamente olvidada durante el resto de la semana; y la administración de ciertos sacramentos (bautismo, confirmación, matrimonio...) constituye un pretexto de las familias para organizar una fiesta («bellas y espléndidas fiestas familiares») y dar un banquete. Se cuida mucho el aspecto externo de los actos religiosos; se da excesiva importancia a la solemnidad oficial, a la ceremoniosidad: decoración del lugar de culto, belleza del pasaje evangélico elegido, elegancia de las vestiduras («largas túnicas» de seda) y palabras del pastor... De esta forma, la Iglesia se transforma en un «teatro»; y la administración de los sacramentos, en una «comedia», cuyos «actores» son los propios sacerdotes ${ }^{5}$.

Esta concepción «estética» que de la religión tenía la Iglesia oficial danesa, y a la que Kierkegaard alude y critica sobre todo en Ejercitación del cristianismo y en los artículos periodísticos aparecidos en los últimos años de su vida, queda reflejada principalmente en dos pasajes de la obra de Ibsen: uno del principio y otro del final. El primero de ellos tiene como protagonista a Ejnar y a Inés; el segundo, al baile y al deán. Personajes éstos que ejercen de portavoces de la concepción estética de la religión oficial danesa, y contra los que se dirigen los reproches de Brand. En dichos pasajes se hace referencia a las principales características que definen esta concepción de la religión.

A la separación entre la fe y las obras o, lo que es lo mismo, a la reduc-

3. IChr, 213-5 у 216-7.

4. Di, $\mathrm{X}^{3} \mathrm{~A} 128$. 358-9.

5. KIERKEGAARD, Bladartikler..., cit., pp. $60,124-5,153-165,235-6,244-7,257-263$, 
ción de la religión a mera doctrina, alude Ibsen varias veces. Semejante idea queda reflejada en las siguientes palabras de Brand a Ejnar en el primer acto: «Separáis la vida de la fe y de la doctrina. Nadie se interesa por ser. Vuestro empeño es elevar el espíritu, pero no vivir entera y plenamente» ${ }^{6}$. A la mitad del acto tercero, Brand le reprocha al baile no haber establecido una unión «entre la vida y la fe» 0 «entre la acción y el ideal» ${ }^{7}$. En el acto quinto, el deán asevera frente a Brand que «hay que separar los conceptos de vivir y creer, pues se anulan al confundirse. Seis días dedicados al trabajo, y el séptimo a la elevación. ¿A qué abrir la Iglesia todos los días? Sería como suprimir el domingo. (...). Contemple el ideal sin temor desde el santo reducto de su cátedra; pero abandónelo con el traje talar cuando haya salido el sol» ${ }^{8}$.

En este último texto también se hace referencia a la reducción de la religión a los actos rituales del domingo, quedando olvidada durante el resto de la semana. Ibsen insinúa esta idea en repetidas ocasiones; un ejemplo de ello lo constituyen las siguientes palabras del baile a Brand: «no convierta los otros seis días de la semana en domingo...» ${ }^{9}$; y las de Brand al pueblo: «...y el Libro yace en el fondo del cofre hasta el próximo día de precepto. (...); seis días de la semana está por los suelos el estandarte de Dios, y sólo al séptimo día se le ve flotar en el cielo" ${ }^{10}$.

A la alianza Iglesia-Estado y al consiguiente servicio que aquélla debe prestar a éste, así como a la transformación de los pastores en funcionarios o empleados de aquél, se refieren explícitamente las palabras que el deán le dice a Brand: «...el Estado ve en la religión la fuerza que más ennoblece el ambiente, el baluarte que defiende su seguridad; en suma: la guía de la moral. (...). Pero este fin estatal, amigo, sólo puede alcanzarse gracias a sus empleados $o$, lo que es igual en este caso, gracias a sus pastores... Ahora ha donado usted la Iglesia en beneficio del Estado y, por consiguiente, su cargo debe dedicarse a procurar la prosperidad de aquél. (...) por medio del donativo del templo ha aumentado usted su compromiso de actuar por la consecución de los fines del Estado a través de su Iglesia» " constituye la amistad y comunidad de intereses que unen al baile (representante del Estado) y al deán (representante de la Iglesia).

El tono festivo que acompañaba a ciertos actos religiosos (concretamente al de la administración del sacramento del matrimonio) queda reflejado, en
6. Brd, 24.
7. Ibid., 106.
8. Ibid., 205.
9. Ibid., 107. Cfr. también 21.
10. Ibid., 220-1.
11. Ibid., 200-3. 
primer lugar, en el cuadro de Ejnar e Inés del primer acto, una pareja de recién casados cuya relación nos recuerda bastante la que Kierkegaard mantuvo con su novia Regina. Inmediatamente después de la exposición de una imagen sombría de la religión definida en torno a Brand, Ibsen nos presenta la concepción contraria de la misma a través de los dos personajes que acabamos de nombrar. Si aquél aparecía como un hombre muy serio envuelto en un halo de niebla, éstos se presentan en medio de una atmósfera radiante de «sol», «luz», «cantos», «baile», «juego», «alegría», «alegría de vivir»...; «población de conceptos ésta con la que Ibsen quiere reseñar el carácter festivo e incluso lúdico que Kierkegaard había descubierto en la religión de la Iglesia oficial danesa. Se trata de dos jóvenes que acaban de casarse, y cuya boda se traduce en una gran fiesta, a la que asisten como invitados, familiares y amigos, entre los que también se encuentran las autoridades políticas y eclesiásticas ${ }^{12}$.

Otra muestra del carácter «estético» de la religión en general nos la ofrece la gran fiesta que quieren organizar las autoridades políticas y eclesiásticas, con motivo de la consagración de la nueva iglesia recién construida. En los textos que describen este hecho se hace referencia a la nobleza de las formas del nuevo edificio, a la belleza del pasaje evangélico del día, a la preparación de un sermón impresionante, a la pompa de las procesiones, a los estandartes de seda, a las copas y candelabros, a los cantos, a las ropas del oficiante, al banquete de comida exquisita que va a dar a los invitados... ${ }^{13} \mathrm{El}$ baile le dice a Brand: «Hoy tiene usted que pronunciar su sermón de manera que retumbe hasta el último extremo del rebaño. Hay tal resonancia, que cuantos me han hablado se muestran llenos de admiración. (...). Sí. El propio deán estaba atónito y lo ha encomiado muchísimo... ¿Qué estilo tan noble el del edificio! ¡Qué vigor en las formas!... Hoy, además, es día de fiesta. (...). Nuestro municipio ha acordado regalarle una copa de plata... Y la canción que se ha compuesto y el discurso que yo he de ofrecer... ha sido usted nombrado caballero. Hoy llevará, como condecoración, la cruz en medio del pecho» ${ }^{14}$. En este mismo tono sigue hablándole el deán al pastor: «Los preparativos de la fiesta, el sermón, me atontan. Lo ensayé ayer; pero todavía se resiste a mi garganta. (...). Reflexione y dígame quién puede competir con usted en abundancia de palabra. (...) ¡Está todo tan espléndidamente adornado!... y el Evangelio del día..., iqué elevado, qué grandioso! Luego, el banquete incomparable... Hace un momento he estado en el presbiterio, donde partían ya la ternera. ¡Un animal excelente, por cierto! Apostaría a que ha costado lo suyo encontrar una

12. Ibid., 13-28.

13. Ibid.

14. Ibid., 192-5. 
pieza tan exquisita en estos tiempos difíciles, cuando la carne está a nueve marcos la libra» ${ }^{15}$. Finalmente, Brand increpa al pueblo, que vive en una «amodorrada tranquilidad»: «¿Qué buscáis en la iglesia? Os atrae su pompa: cántico de campanas y de órgano, deseo de que os impresione la fogosidad de un verbo ardiente con su chisporroteo que silba y crepita, que chorrea, truena y estalla según las reglas del arte. (...). Lo que anheláis son los candelabros de las solemnidades y lo externo" ${ }^{16}$.

De todos estos textos referentes a la religión de la Iglesia establecida danesa se desprende claramente que ésta tenía una concepción «estética» de la religión; concepción ésta en la que la vida del creyente se caracteriza por el bienestar, goce y ausencia de sacrificios, como nos lo confirman las siguientes palabras del baile y del deán al pueblo: «...no exige sangre ni acero y os aporta el bienestar sin sacrificio personal. (...). Seremos benévolos, ciertamente...» ${ }^{17}$, Los jerarcas de la Iglesia establecida predican un cristianismo melifluo, muy «humano», el cual no exige holocaustos ni víctimas ${ }^{18}$.

\subsection{Religión ascética}

Frente a la religión estético-especulativa, reducida a simple doctrina, que defendían los hegelianos daneses, Kierkegaard afirma numerosas veces con gran énfasis que la religión es esencialmente práctica, práctica ascética.

Por el hecho de que la verdad cristiana se presente como paradoja y, consiguientemente, como algo incomprensible, quiere decirse que no es objeto de saber o especulación para el hombre, sino objeto de asimilación existencial: no es una verdad para aprender, sino más bien una verdad para realizar ${ }^{19}$. El autor danés no ve la religión (cristiana) como una mera doctrina ${ }^{20}$, sino sobre todo como una forma de existencia (existens), un modo de ser, una práctica, una vida. «Lo cristiano, que no se relaciona al conocimiento, sino a la acción (Handle), encierra la peculiaridad de responder de tal manera que la respuesta le constriña a cada uno a la tarea» ${ }^{21}$. Por tanto, el individuo religioso auténtico no es el que se limita a conocer y señalar el camino, sino el que lo recorre.

A la importancia que en la concepción kierkegaardiana de la religión tie-

15. Ibid., 197-9. Cfr. también 73-4 y 104.

16. Ibid., 219-220.

17. Ibid., 236.

18. Ibid., 111, 138, 139. «Lo humano y lo cristiano se identifican perfectamente»: ésa es la tesis, el santo y seña de nuestra época. Pero es la exacta expresión de la abolición del cristianismou. (Di, X ${ }^{4} \mathrm{~A} 258$.

19. KLEIN, A., Antirazionalismo di Kierkegaard. Milano, 1979, pp. 103-5.

20. «El cristianismo no es ninguna doctrina». (IChr, 101).

21. $K G, 94$. 
ne las «obras», se refiere indirectamente Ibsen con los reproches que hace Brand a varios personajes por haber separado la vida de la fe, tal y como nos manifiestan los textos que hemos indicado en el apartado anterior. Pero aún existen otras afirmaciones en la obra que apuntan directamente a esta cuestión de la unidad esencial de la doctrina y los hechos en la religión. Una de ellas viene constituida por las palabras de un hombre anónimo que, tras haber contemplado la hazaña de Brand sobre las aguas tempestuosas del fjord, le dice al pastor: «Muchos antes que tú nos han dicho y enseñado dónde estaba el camino. Ellos lo señalaban, pero tú lo has seguido. (...). No se graban mil palabras como las huellas de un solo hecho» ${ }^{22}$. Otra afirmación al respecto la constituyen las palabras que Brand dirige a la multitud que lo sigue ascendiendo la montaña en el acto quinto: «Todo está cubierto por la Iglesia, igual que el tronco por su corteza, amalgamándose vida y fe. Ella unirá la faena del día con la ley y el dogma» ${ }^{23}$. En fin, a esta misma idea apunta el baile, cuando le dice a Brand: «por lo que advierto, su idea es combinar la vida con sus ideales» ${ }^{24}$; y el mismo Brand, cuando le advierte a Ejnar: «No, yo no soy un «sermoneador». No hablo como el pastor de la Iglesia» ${ }^{25}$, lo que equivale a decir que la religión no es cuestión de sermones, de palabras, de mera doctrina..., sino de hechos.

A su vez, Kierkegaard identifica la religión cristiana, en cuanto vida o forma de existencia que es, con un camino (Vei) ${ }^{26}$. Pero no con un camino fácil y trillado, por el que se anda con placer, sino con un camino estrecho, angosto y escabroso, por el que se va con mucha dificultad y displacer. El sufrimiento (Lidelse) es una cualidad esencialmente inherente al camino cristiano: «...son una y la misma cosa, que la tribulación es el camino (cristiano), y que el camino es tribulación; se pertenecen tan estrechamente la una a la otra que... son un concepto» ${ }^{27}$. Y este sufrimiento debe ser constante ${ }^{28} \mathrm{y}$, además, voluntario: «sufrir por la doctrina, querer sufrir por la doctrina, no el sufrir incidentalmente por ella por casualidad» ${ }^{29}$.

Ahora bien, definir al cristiano por el sufrimiento equivale a convertirlo en un asceta (asket), en un individuo que muere al mundo y se niega a sí mis-

22. $B r d, 54-5$.

23. Ibid., 222.

24. Ibid., 104.

25. Ibid., 21 .

26. IChr, 190-3.

27. OTfA, 380 .

28. KIERKEGAARD, Til Selvprovelse Samtiden Anbefalet, en Samlede Vaerker, cit., 1905, vol. XII, p. 343.

29. Id., Dommer selv! Til Selvprovelse Samtiden Anbefalet, en Samlede Vaerker, cit., 1905 , vol. XII, p. 468. 
mo. Pero esta renuncia no debe ser parcial, sino total y absoluta, ya que «ningún hombre puede servir a dos señores». El imperativo de negación de sí mismo es una exigencia de abnegación total, correlativa de una elección absoluta de Dios. «....absolutamente distinto del mundo sirviendo solamente a Dios... $\mathrm{Y}$ en esto consiste la piedad cristiana: en renunciar a todo con el fin de servir sólo a Dios» ${ }^{30}$. La renuncia parcial al mundo o la elección relativa de Dios equivale a una elección del mundo. Lo correcto es la elección exclusiva de Dios, del Bien; de ahí el título de aquel escrito religioso publicado en 1847: $L a$ pureza de corazón consiste en querer una sola cosa: el bien, lo que excluye tener «dos voluntades» o una «doble inclinación» ${ }^{31}$.

Así, pues, estrechez del camino, sufrimiento constante y voluntario, renuncia total al mundo..., son características esenciales de la concepción kierkegaardiana de la religión. Características éstas que configuran una imagen macabra del cristianismo, la cual es una consecuencia de la severa educación religiosa que Kierkegaard recibió del padre durante la infancia ${ }^{32}$ : éste nunca le hablaba del Niño Jesús, sino que lo ponía ante un crucifijo ensangrentado; más que hablarle del Cristo resucitado y glorioso, le hablaba del Cristo de la pasión, con la cruz a cuestas camino del Calvario ${ }^{33}$.

Todas estas características que Kierkegaard atribuye a la religión cristiana, aparecen perfectamente reseñadas y resaltadas en torno a la figura de Brand a lo largo de la obra de Ibsen.

A la escabrosidad del camino cristiano apunta el dramaturgo noruego de un modo indirecto mediante el halo de niebla que envuelve a Brand: en la obra de Ibsen, el símbolo de la niebla no sólo significa la irracionalidad de la concepción kierkegaardiana de la religión (como hemos señalado en el apartado 3.2.1.), sino también la dificultad que entraña la vida cristiana para el creyente. Otra muestra indirecta de dicha dificultad viene constituida por el paraje donde se ubica el hogar de Brand e Inés, un lugar «áspero, frío, poco acogedor..." ${ }^{34}$.

Pero a esta misma nota también apuntan directamente muchas palabras puestas por Ibsen en boca de Brand. Al principio del primer acto, el pastor le reprocha al campesino el haber elegido el camino «más ancho», en el que no

30. Ibid., 440 .

31. OTf $A, 139,141,144-5,151,164,167,178-9$. Por esta exigencia de sacrificio y renuncia total a sí mismo, el cristianismo de Kierkegaard ha sido tachado de «inhumano» por N.F.S. Grundtvig, teólogo contemporáneo de Kierkegaard y defensor de la tesis de que el cristianismo no excluye lo humano o natural de la vida del hombre (cf. HARBSMEIER, G., Kierkegaard und Grundtvig, en SCHREY, H.H., Sören Kierkegaard. Darmstadt, 1971, pp. 395-8.

32. Di, VIII ${ }^{1}$ A 663 .

33. Cfr. Castellani, L., De Kierkegaard a Tomás de Aquino, Buenos Aires, 1973, p. 72.

34. Brd, 80 . 
hay «cruces» ${ }^{35}$. Al comienzo del segundo, le recuerda a Inés el haberla prevenido «para un camino penoso» ${ }^{36}$. Unas páginas más adelante, contrapone el camino «angosto y escarpado» al «ancho camino del pecado» ${ }^{37}$. Nada más empezar el acto cuarto, le dice a Inés que «el camino lleva hacia lo alto» ${ }^{38}$, con lo que da a entender que hay que subir y, por tanto, sacrificarse. Cerca del final de este mismo acto, cuando Brand exige a Inés el sacrificio de desprenderse de los recuerdos del hijo recién muerto, ésta confiesa que el camino del Dios de su esposo es «empinado y estrecho»; a lo que Brand responde que «sólo existe ese camino», un camino «pavimentado con piedras de sacrificio» ${ }^{39}$.

Especialmente significativo a este respecto es el segundo cuadro del último acto. En él, Ibsen escenifica una especie de viacrucis. Describe la ascensión de Brand (Cristo) hacia la cumbre de una montaña, donde morirá sepultado por un alud. Tras él camina el pueblo quejándose de la hosquedad y de lo abrupto de los parajes atravesados, del hambre, de la sed, del cansancio..., que padece por el camino. En esta peregrinación, Brand le enseña que «el camino empinado es el más corto» ${ }^{40}$, y le advierte: «pasa por el desierto del sacrificio la ruta que nos lleva a Canaán. ¡Ganemos la victoria cayendo! ¡Sed todos campeones del Señor!» ${ }^{41}$.

En este mismo cuadro alude Ibsen a la constancia del sacrificio a realizar por el individuo religioso. Cuando la multitud, cansada de pisar los talones de Brand ascendiendo la cuesta, le pregunta al líder «cuánto durará la lucha», éste le responde: «hasta el fin de vuestra vida, hasta que hayáis sacrificado todo y os hayáis desligado de todos los compromisos...» ${ }^{42}$.

$\mathrm{Al}$ menos tres textos nos recuerdan la importancia que tiene el aceptar voluntariamente el sacrificio inherente a la existencia religiosa. De ellos, dos son los más significativos por la extensión y énfasis que ponen en dicha idea. Ambos contienen palabras de Brand a Inés. El primero dice así: «ante todo, hay que querer... Con fuerza y alegría se debe querer en medio de la multitud de angustias. No es un martirio recibir muerte dolorosa sobre el madero de una cruz. Es necesario querer la muerte en la cruz, quererla entre los sufrimientos de la carne, quererla en medio de las angustias del espíritu...» ${ }^{43}$. El segundo

35. Ibid., 10.

36. Ibid., 80.

37. Ibid., 89.

38. Ibid., 134 .

39. Ibid., 161.

40. Ibid., 228.

41. Ibid., 231.

42. Ibid., 230.

43. İbid., 89-90. 
se refiere al doloroso y finalmente voluntario desprendimiento de la ropa del hijo muerto que hace Inés ${ }^{44}$.

Pero la idea que más resalta Ibsen dentro de esta concepción ascética que de la religión tenía Kierkegaard, es la de la renuncia absoluta a lo mundano. El dramaturgo noruego hace referencia numerosas veces al lema de Brand: «itodo o nada!». Lema éste que expresa el imperativo religioso de desprendimiento total de aquello a lo que el hombre se adhiere instintivamente: riqueza, mujer, hijos, vida... Según Brand, el Dios de la religión cristiana no se conforma con una parte de lo que posee el creyente: no se contenta con poco, ni con mucho, ni con la mitad, ni con casi todo. Lo exige todo, absolutamente todo, incluso la vida; de ahí que afirme Inés: «el que ve a Jehová, muere» ${ }^{45}$, muerte a la vida mundana. El sacrificio parcial es inútil: «el sacrificio incompleto es algo arrojado al mar» ${ }^{46}$. No renunciar a todo, desprenderse sólo de una parte, equivale a no renunciar a nada: a servir a dos señores, a Dios y al mundo; por eso Brand aconseja: «no dirijáis, como ahora, un ojo hacia el cielo y otro hacia el suelo'» ${ }^{47}$.

A lo largo de la obra, Brand pone ante esta alternativa del «itodo o nada!» a varios personajes: al campesino, a la madre, a Inés... Al campesino le pregunta si daría la vida por que su hija muriese tranquila ${ }^{48}$. A la madre le pide que renuncie a todas sus riquezas ${ }^{49}$. A Inés le exige que se desprenda de todas las ropas del hijo muerto y de todos los recuerdos del mismo ${ }^{50}$. Por haber adoptado este lema de la renuncia absoluta, muchos personajes le reprochan ser muy duro, y le piden que no exija tanto: « ¡Brand, eres duro!» ${ }^{51}$, le dice Inés; «¡no exijas tanto!», le suplican varias personas tras pedirles que den « ihasta la muerte, hasta la tumba!» ${ }^{52}$.

El cumplimiento de esta dura exigencia de renuncia absoluta a lo mundano trae consigo la plena libertad del alma, imagen de Dios en el hombre: libera de la esclavitud a la que tienen a uno sometido los instintos arraigados en el cuerpo ${ }^{53}$. De ello nos da fe Inés, quien, tras haberse despojado de todos los

44. Ibid., 172-4.

45. Ibid., 162, 175. En Kierkegaard estas palabras del Éxodo («ver a Dios y morir») no significan tanto la renuncia al «cuerpo» (bienes materiales) cuanto la renuncia a la razón que tiene que hacer el creyente. (Cfr. $D i$, V A 78).

46. Brd, 160.

47. Ibid., 54.

48. Ibid., 7.

49. Ibid., $71,91-5$.

50. Ibid., 161-172.

51. Ibid., 80.

52. Ibid., 46.

53. También Kierkegaard distingue entre alma (libertad) y cuerpo en el hombre; y considera al alma como un reflejo de Dios. (Cfr. $B A, 351 ; O T f A, 278 ; B r d, 69,131$ ). 
lazos que la ataban a la vida terrena, exclama: «¡Soy libre! ¡Brand, soy libre! (...). ¡Ha llegado el triunfo en la lucha de la voluntad!» ${ }^{54}$. A esta misma idea apuntan las siguientes palabras de Brand al cerrar el acto cuarto: «La victoria de las victorias es perderlo todo. El todo que se pierde engendra la riqueza... ¿Sólo se posee enteramente lo perdido!» ${ }^{55}$. Estos textos nos recuerdan la categoría kierkegaardiana de la «repetición» (Gjentagelse) o reconquista de la libertad perdida en la caída del pecado original ${ }^{56}$.

No obstante este rigorismo, en la obra de Ibsen también se encuentran algunas afirmaciones que parecen atenuar un poco la excesiva dureza de la concepción religiosa de Brand. Según éstas, Dios no exige al hombre más de lo que éste puede dar; si al individuo le faltan fuerzas para cumplir plenamente una tarea, no tiene la obligación de realizarla en su totalidad. «iDonde no hay fuerza no hay misión! Si no puedes ser lo que debes, sé con seriedad lo que puedes» ${ }^{57}$. Cuando no se puede satisfacer plenamente la exigencia, Dios se conforma con la voluntad o el esfuerzo del individuo en su intento de cumplir la tarea. Es ésta la idea que parece expresar la súplica de Brand al final de la obra: «iEn el umbral de la muerte, dime, Dios, si no supone un asomo de salvación la fuerza de voluntad!...» ${ }^{58}$. Súplica ésta a la que sigue la exclamación de una voz anónima: «¡El es Deus caritatis!».

Así, pues, si desde el carácter irracional del cristianismo el individuo auténtico kierkegaardiano, tal y como se refleja en la obra de Ibsen, quedaba definido por el coraje, desde el carácter práctico queda definido por la acción: el verdadero individuo religioso es el que obra de acuerdo con su fe: el que traduce la fe a hechos. Así nos lo insinúa el hombre que pide a Brand se quede como pastor en la parroquia: «No se graban mil palabras como las huellas de un solo hecho. Venimos a buscarte en nombre del distrito. Bien vemos que es justamente un hombre lo que nos hace falta» ${ }^{59}$.

\section{DE LA RELIGIÓN POÉticA A LA PATÉticA}

Al final del apartado 2 citábamos un texto de Ibsen al que considerábamos como un resumen anticipado de la crítica que Kierkegaard hizo de la realidad religiosa de su época. En dicho texto se habla de tres tipos de individuos,

54. Brd, 174.

55. Ibid., 178.

56. KIERKEGAARD, Gjentagelsen, en Samlede Vaerker, cit., 1901, vol. III, pp. 253-4.

57. Brd, 58.

58. Ibid., 261. Cfr. también 135.

59. Ibid., 55. 
que encarnan tres concepciones erróneas de la religión: «el espíritu ligero» (el campesino), en el que predomina la facultad de la razón; «el espíritu débil» (Ejnar), definido por la sensibilidad; y «el espíritu salvaje» (Gerda), dotado de una portentosa imaginación. A los dos primeros nos hemos referido en los apartados 3 y 4, respectivamente; del tercero, que es una especie de síntesis de los dos anteriores, vamos a tratar ahora.

La categoría de la imaginación adquiere suma importancia dentro del romanticismo. Kierkegaard, en tanto que representante de este movimiento cultural, también trata dicha categoría. Pero no la presenta en el contexto de la religión, sino en el de la estética. Un tipo de individuo estético es el esteta soñador. Éste se presenta como un hombre dotado de una vigorosa imaginación (Phantasi) ${ }^{1}$, capaz de crear o recrear los mundos fantásticos más inverosímiles a base de modificar la realidad existente. Toda su actividad creativa se reduce a transformar la realidad cotidiana en una entidad ficticia, poética..., para luego gozar de la contemplación de esos bellos «poemas» ${ }^{2}$.

En la obra de Ibsen la categoría de la imaginación aparece en el ámbito de la religión y, concretamente, en torno al personaje llamado Gerda, una niña gitana a la que los demás tienen por loca. Al final del primer acto, Gerda aparece persiguiendo a un azor, al que arroja piedras con intención de abatirlo ${ }^{3}$. Tanto la niña como el vuelo del azor simbolizan la imaginación, el vuelo de la imaginación de los individuos religiosos inauténticos. Imaginación que transforma la realidad fea y cruel en otra más hermosa: convierte el duro rigorismo y severidad de la religión en blandura y molicie. Gerda, el individuo religioso inauténtico, es un «espíritu salvaje, con tal vuelo de fantasía (slig en flugt), que cuanto de malo ve lo transforma en hermoso» ${ }^{4}$.

La religión que concibe Brand (individuo religioso auténtico) no coincide con la que concibe Gerda (individuo religioso inauténtico), porque aquél la mira con los ojos realistas de la fe, mientras que ésta la contempla con la mirada fantástica de la imaginación. En la «iglesia hecha de hielo y nieve», a la que «una laguna helada le sirve de suelo y asiento», Brand ve una Iglesia constituida por el sacrificio y el riesgo; en cambio, Gerda contempla una Iglesia grande y hermosa, distinta de la que se erige en el valle, la cual «es fea... porque es muy pequeña» 5 . Brand capta la severidad e inseguridad que para el creyente representa la religión, mientras que la imaginación de Gerda transforma estas

1. KiERKEGAARD, Gjentagelsen, cit., pp. 180, 218-9. Id., Enten-Eller, 1.Del, en Samlede Vaerker, cit., 1901, vol. I, p. 20.

2. Ibid., p. 277.

3. $B r d, 31-5$.

4. Ibid., 35 .

5. Ibid., 32-5. 
horrorosas características reales de la religión en otras ficticias más hermosas y placenteras. Por ello cabe decir que Gerda, su imaginación, no capta la esencia de la religión, la severidad y el riesgo que ésta entraña para el creyente. La imaginación de Gerda contempla la religión por fuera; sólo se fija en el aspecto externo de la misma; no desciende desde la superficie al núcleo, como hace Brand. Esta idea nos la expresa simbólicamente el siguiente texto. «Allá arriba la cascada y el alud ofician la misa. Allá predica el viento sobre la superficie del helero, dando frío y calor a un tiempo. Y el azor (imaginación) jamás puede entrar; se instala sobre el Svartetind y allí se queda posado, el muy bribón, como gallo de veleta sobre la iglesia» ${ }^{6}$.

La contraposición de las concepciones de la religión de Gerda y de Brand también se refleja en las diferentes ideas que de Dios tienen Brand y los demás personajes; ideas éstas respectivamente equivalentes a la de Kierkegaard y los representantes de la Iglesia oficial danesa.

La imaginación de los individuos pertenecientes a la cristiandad establecida, concibe a Dios como un viejo canoso, de pelo escaso, de luengas barbas como hilos de plata, con anteojos y gorro de dormir, débil, benigno (velvilligt), bonachón, permisivo... ${ }^{7}$.

En cambio, el Dios de Brand es un Dios joven y fuerte como Hércules. Es un huracán (storm): un dios duro, cuya voz resuena acompañada del rayo y del espanto. Su amor no es débil y suave, sino duro hasta el horror de la muerte: un amor que acaricia hasta hacer daño ${ }^{8}$. Más que «Padre» (fader), cercano a sus hijos, es «Señor» (herre), distante de los hombres: «un rey en su castillo», al que da miedo dirigirse; un «Dios todopoderoso», grande, que «está sentado en su trơno sobre la bóveda de las nubes», en «las alturas», desde donde juzga y castiga a los hombres: un Dios juez, que hace reinar la justicia y no perdona al que infringe su ley ${ }^{9}$.

Esta concepción de Dios como «Majestas», característica de la teología protestante ${ }^{10}$, implica que entre Dios y el hombre media una distancia infinita: frente a la grandeza de Dios el hombre aparece como un ser sumamente pequeño; Aquél es un «gigante» (kaempe), mientras que éste, «el enano (dverg) de los enanos», «el más humilde gusano de la tierra» ${ }^{11}$. Por ello, el hombre nunca podrá llegar a ser como Dios. «Lo mismo que él nunca podrás llegar a

6. Ibid., 34-5.

7. Ibid., 23-4, 238-9.

8. Ibid., 24-5, 84, 129-130.

9. Ibid., 112, 129-130, 132, 218-9.

10. Cfr. Otro, R., Lo santo. Lo racional y lo irracional en la idea de Dios, Madrid, 1980, pp. 31-7.

11. $B r d, 25,257$. 
ser tú, pues naciste de la carne. (...). Lo mismo que él, vil gusano, nunca llegarás a ser....» ${ }^{12}$.

En los escritos de Kierkegaard también está presente la idea de Dios como «Majestas», así como la de la consiguiente distancia infinita del hombre con respecto a él. Para el pensador danés, Dios es «el Omnipotente», «el Todopoderoso» (den Almaegtige) ${ }^{13}$, ante el que el hombre siente «temor y temblor» (Frygt og Baeven), y del que está infinitamente alejado. «Dios y el hombre son dos naturalezas separadas por una infinita diferencia cualitativa» ${ }^{14}$.

Así, pues, tal y como se refleja en la obra de Ibsen, frente a la blanda religión poética de los hegelianos daneses, producto de su imaginación, Kierkegaard pone una religión patética, cuya esencia viene constituida por el riesgo inherente al creyente y por la excesiva severidad de un Dios todopoderoso.

\section{CONCLUSIONES}

Como hemos apuntado al principio de este trabajo, Ibsen trata de reflejar sobre todo la concepción kierkegaardiana de la religión: Brand es ante todo una expresión poética («indirecta») de las ideas religiosas de Kierkegaard. El dramaturgo noruego alude a los temas y categorías más importantes de la visión kierkegaardiana de la religión: irracionalidad, praxis, elección, riesgo de la fe, suspensión teológica de la ética, ascetismo, omnipotencia y justicia de Dios... Pero también hace referencia a hechos biográficos, algunos de los cuales influyeron en la configuración del pensamiento del danés: la soledad, el noviazgo, la intención de abandonar la profesión de escritor y llegar a ser pastor en una parroquia rural, la inversión de la herencia que recibió del padre en la confección y edición de los escritos, el peso de los pecados del padre sobre la vida de los hijos...

Todos estos temas aparecen dispersos a lo largo de la obra de Ibsen sin orden alguno. Los más subrayados son los de la irracionalidad, la elección, la exigencia absoluta del «todo o nada», y el riesgo de la fe. En relación a esta última categoría queremos anotar que Kierkegaard no resalta tanto el «riesgo» cuanto la «pasión» del creyente; pasión ésta que es una consecuencia del riesgo inherente a la fe.

Dos categorías importantes del pensamiento de Kierkegaard, con cuyo nombre se suelen asociar, son las de «angustia» y «desesperación». La primera de ellas aparece numerosas veces en el texto de Ibsen, pero no refleja el sig-

\footnotetext{
12. Ibid., 247.

13. $K G, 259$ y 343-4. FB., 74 KIERKegAARd, Philosophiske Smuler, cit., p. 187.

14. $S D, 235$. Cfr. también $D i, \mathrm{X}^{3} \mathrm{~A} 186$.
} 
nificado que le confirió Kierkegaard, al menos el que le quiso dar en El concepto de la angustia. La segunda brilla por su ausencia en la obra de Ibsen; éste no hace ninguna referencia a la misma.

De un modo general, creemos que Ibsen refleja bastante bien en su obra el pensamiento religioso de Kierkegaard, lo cual sólo puede ser resultado de una lectura amplia y atenta de los escritos del autor de Copenhague.

Jaime FRANCO BARRIO

Universidad de Salamanca 